\title{
WestVirginiaUniversity
}

THE RESEARCH REPOSITORY @ WVU

Graduate Theses, Dissertations, and Problem Reports

2003

\section{Corrosion of high-chromium and conventional steels embedded in concrete}

Vijayakumar Nachiappan

West Virginia University

Follow this and additional works at: https://researchrepository.wvu.edu/etd

\section{Recommended Citation}

Nachiappan, Vijayakumar, "Corrosion of high-chromium and conventional steels embedded in concrete" (2003). Graduate Theses, Dissertations, and Problem Reports. 1390.

https://researchrepository.wvu.edu/etd/1390

This Thesis is protected by copyright and/or related rights. It has been brought to you by the The Research Repository @ WVU with permission from the rights-holder(s). You are free to use this Thesis in any way that is permitted by the copyright and related rights legislation that applies to your use. For other uses you must obtain permission from the rights-holder(s) directly, unless additional rights are indicated by a Creative Commons license in the record and/ or on the work itself. This Thesis has been accepted for inclusion in WVU Graduate Theses, Dissertations, and Problem Reports collection by an authorized administrator of The Research Repository @ WVU. For more information, please contact researchrepository@mail.wvu.edu. 


\title{
Corrosion of High-Chromium and Conventional Steels Embedded in Concrete
}

\author{
Vijayakumar Nachiappan \\ Thesis \\ Submitted to the \\ College of Engineering and Mineral Resources \\ at West Virginia University \\ in partial fulfillment of the requirements for the degree of
}

Master of Science in

Mechanical Engineering

\author{
Dr. Kenneth H. Means, Chair \\ Dr. Eung Ha H. Cho, Co-Chair \\ Dr. Hota V. GangaRao \\ Dr. Bruce Kang \\ Department of Mechanical Engineering \\ Morgantown, West Virginia \\ 2003
}

Keywords: Corrosion, Steel, Concrete, Testing, X-ray Diffraction, Chloride Analysis

Method, Particle Size Distribution, Corrosion Product Analysis, Linear Polarization 


\title{
Abstract \\ Corrosion of High-Chromium and Conventional Steels Embedded in Concrete
}

\author{
Vijayakumar Nachiappan
}

Corrosion of steel in concrete structures sometimes led to the unexpected failure of the concrete bridges in United States before their intended service life. High-chromium steel has been developed as a replacement for conventional steel in concrete because it may have a capability to retard the corrosion rate. In the present study, high-chromium and conventional steels were subjected to accelerated corrosion, and compared for their corrosion performance under chloride environment.

Corrosion rates of high-chromium and conventional steel rebars were compared by conducting two studies. One was with concrete blocks and the other was with bare steel rebars. In the former study, concrete blocks which had been made with two different steel rebars were placed in sodium chloride solutions and air was blown through the solutions to accelerate corrosion of the steel rebars. These blocks were taken out of the solution periodically and the corrosion rates of the embedded rebars were measured with 3-LP device. In a latter study, the bare rebars of the two steels were also corroded in sodium chloride solutions through which air was blown, withdrawn periodically, dried, weighed after the corrosion products were removed. The corrosion rates were measured by the reduction of the weight of the rebars.

In the concrete block study, it was found that corrosion rate increases as the concentration of sodium chloride increases for both steels. It was also found that the corrosion rate of concrete blocks made of conventional steel was about twice as much as that of the concrete blocks made of high-chromium steel after 132 day exposure. From corrosion study with bare steel rebars, it was found that the rate of corrosion of conventional steel was 12 times as much as that of high-chromium steel at $0.1 \%$ sodium chloride and the ratio decreased to 2 times as sodium chloride concentration increased to $3 \%$. It was found that the corrosion rate of high-chromium steel was very sensitive to sodium chloride concentration; i.e., the corrosion rate increased as the concentration increased. However, the corrosion rate of conventional steel was not sensitive to sodium chloride concentration.

The corroded products were analyzed using X-ray diffraction and Atomic Absorption Spectroscopy to identify the minerals present in them. The corroded products with iron formed on the surface of high-chromium steel, were predominantly lepidocrocite $(\gamma-\mathrm{FeOOH})$ and hematite $\left(\mathrm{Fe}_{2} \mathrm{O}_{3}\right)$ while that on the surface of conventional steel was predominantly magnetite $\left(\mathrm{Fe}_{3} \mathrm{O}_{4}\right)$. It is surmised that the former iron oxides form a more resilient and adherent passive film than magnetite, which can explain the distinct difference in corrosion rates of two steel rebars. 


\section{Acknowledgements}

I would like to express my heartfelt gratitude and appreciation to my research advisor Dr. Eung Cho for his excellent guidance, support and patience throughout this project. I am very much indebted to Dr. Hota GangaRao for providing financial assistance for this venture and thank him for his valuable guidance and suggestions during the course of this project. I would like to thank my committee members Dr. Kenneth Means and Dr. Bruce Kang for being supportive and helpful. I express my sincere thanks to Dr. Manivannan Ayyakkannu for providing an opportunity to utilize the X-ray diffraction facility. I also thank Dr. Vijay, Mr. Ram Chamarthy and other staff members of the Constructed Facilities Center for their contribution to the successful completion of this project. I would also like to thank Mr. Dana Humberson and Mr. Jim Hall for their help provided in the laboratory. Finally I would like to thank my family members and my friends for providing support and guidance during the period of my graduate study. 


\section{Table of Contents}

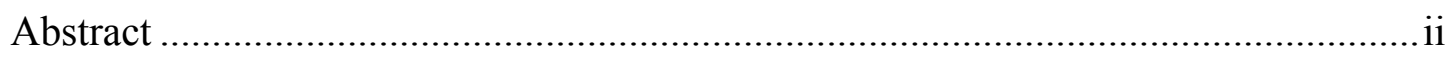

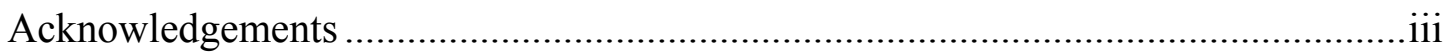

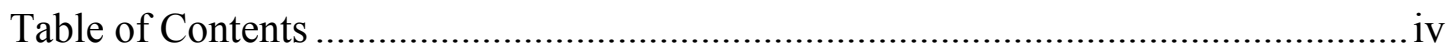

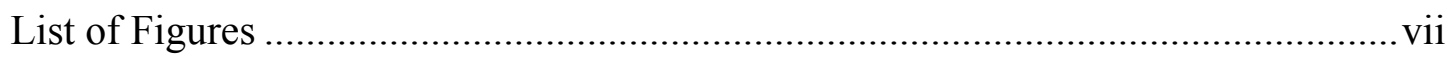

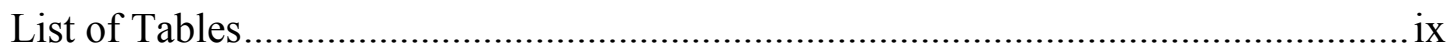

Chapter 1

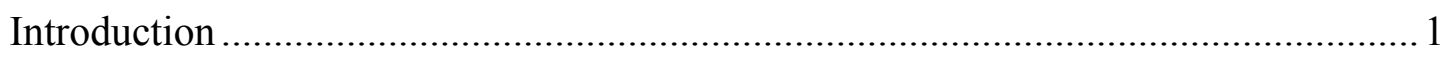

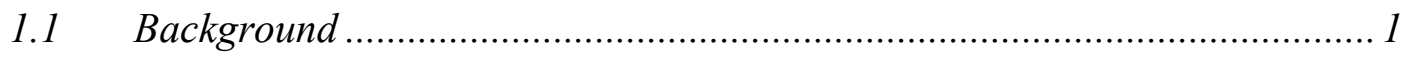

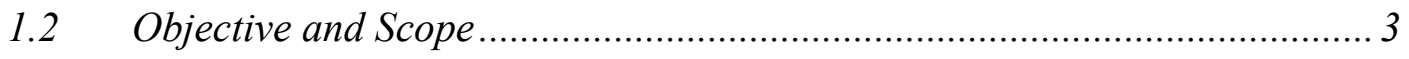

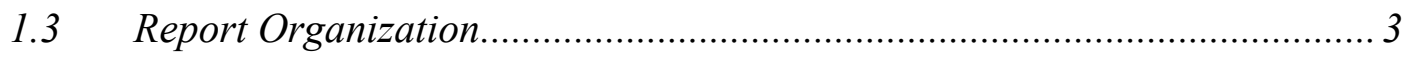

Chapter 2

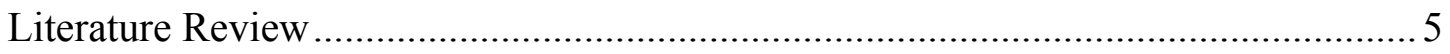

2.1 Mechanism of Corrosion of Steel in Concrete ........................................... 5 
2.2 Factors Influencing Corrosion of Steel in Concrete .................................. 8

2.3 Corrosion Protection Techniques ............................................................ 9

2.4 Characteristics of Corrosion Products on Steel Rebars ........................... 10

$2.5 \quad$ Need for Corrosion Monitoring ...................................................... 11

2.6 Corrosion Monitoring Techniques ................................................... 11

2.7 Linear Polarization Resistance Method ................................................ 13

2.8 Theory of Linear Polarization.......................................................... 14

2.9 Limitations of Polarization Resistance Measurements ............................ 14

Chapter 3

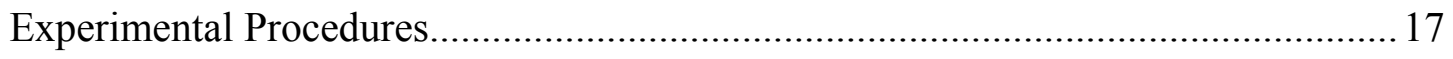

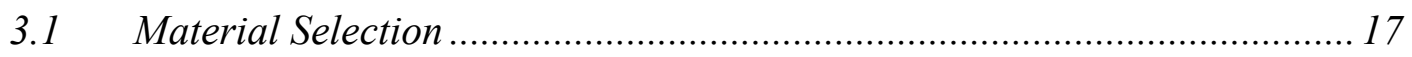

3.2 Test Specimen Preparation ............................................................. 21

3.3 Corrosion Study of Concrete Blocks ................................................. 23

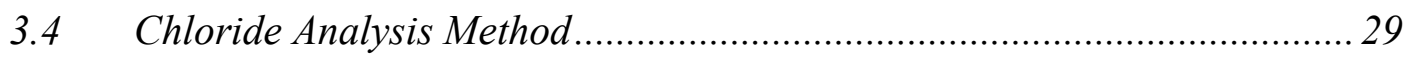

3.5 Corrosion Study of Bare Steel Rebars................................................. 30

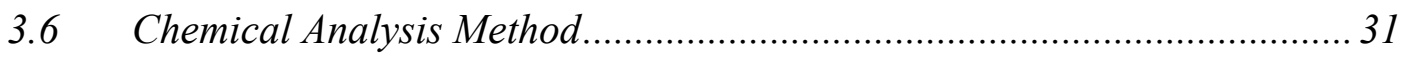

3.7 Particle Size Distribution Analysis .................................................... 32

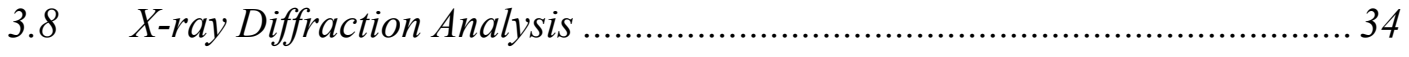


Chapter 4

Results and Discussion 36

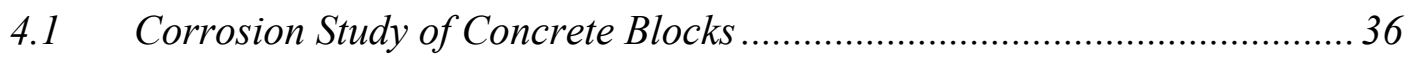

4.2 Chloride Analysis Method ............................................................... 41

4.3 Corrosion Study of Bare Steel Rebars............................................... 42

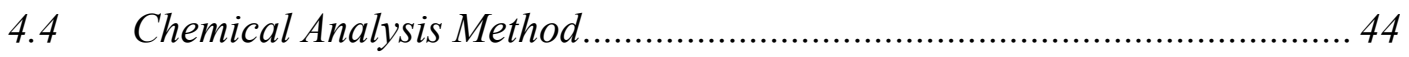

4.5 Particle Size Distribution Analysis ....................................................... 46

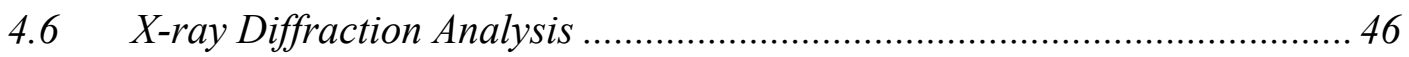

Chapter 5

Conclusions

Chapter 6

References

Appendix 53

Experimental Data. 53 


\section{List of Figures}

Figure 1: Stress-strain curves for high-chromium and conventional steel rebars .................. 19

Figure 2: Concrete blocks coated with epoxy on two sides ......................................... 22

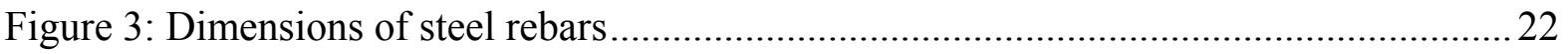

Figure 4: Galvanostatic circuit for corrosion rate measurements ...................................... 25

Figure 5: Typical polarization curves showing anodic and cathodic Tafel slopes................ 25

Figure 6: Experimental set up of concrete blocks immersed in sodium chloride solution .....26

Figure 7: Air bubbling through the sodium chloride in between the concrete blocks ...........26

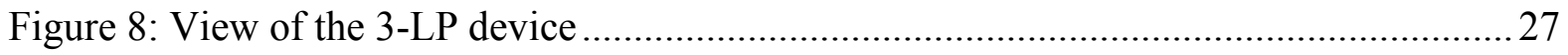

Figure 9: Experimental setup for 3-LP device ........................................................... 27

Figure 10: Corrosion products on the surface of the steel showing reddish brown product in HC steels (left) and black products in the CV steel (right) ............................... 31

Figure 11: Variation of potential with respect to current for specimen -8 (HC steel) after 132 days of immersion in $3 \%$ of sodium chloride ................................................... 37

Figure 12: Variation of potential with respect to current for specimen - 12 (CV steel) after 132 days of immersion in $3 \%$ of sodium chloride 37

Figure 13: Comparison of variation of potential respect to current for specimens 8 and 12 .. 38

Figure 14: Average corrosion rate of steel in concrete over time period............................. 39

Figure 15: Corrosion regions of a concrete pile in a marine environment ..........................40

Figure 16: Average percent weight loss of $\mathrm{HC}$ and $\mathrm{CV}$ steel in sodium chloride solutions ... 43

Figure 17: Particle size distribution for corrosion products .......................................... 47

Figure 18: X-ray diffraction analyses on corrosion products of CV steel .......................... 48 
Figure 19: X-ray diffraction analyses of corrosion products on $\mathrm{HC}$ steel ....... 


\section{List of Tables}

Table 1 Relationship between corrosion rate and possible damage in years ....................... 16

Table 2 Chemical constituents of high-chromium steel (wt \%) ........................................ 18

Table 3 Chemical constituents of conventional steel (wt \%) ........................................... 18

Table 4 Proportions of primary anhydrous mineral phases in Type 1 Portland cement .........20

Table 5 Mix volume and volume proportions of concrete used.....................................20

Table 6 Test matrix for concrete blocks reinforced with steel ........................................ 23

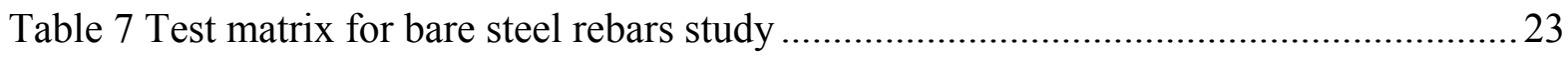

Table 8 Average concentration of chloride ions in concrete blocks in PPM ...................... 42

Table 9 Percent weight loss/corrosion rate of HC and CV steel rebars ............................. 44

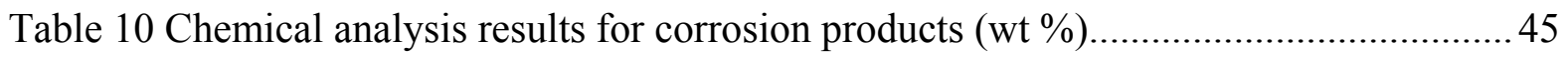

Table 11 Corrosion rate of steel in concrete blocks in 1.7 and $3 \%$ sodium chloride ............ 54

Table 12 Percent weight loss of HC and CV steel rebars in different sodium chloride.......... 56 


\section{Chapter 1}

\section{Introduction}

\subsection{Background}

Corrosion is the result of chemical reaction between a metal and its environment. It is the tendency of the refined metal to return to its mineral state. The total direct cost of corrosion and its protection in United States is estimated to be around \$276 billion dollars in

the year $2001^{1}$. Corrosion of reinforcing steel in concrete is found to be a major problem not only from economic point of view, but also from safety. The National Bridge Inventory Database for bridges in United States shows that approximately $15 \%$ of bridges are structurally deficient due to corrosion of steel in the year 1999. The repair and replacement costs for these aging bridges were increased by $12 \%$ during the same period ${ }^{1}$. The repair and maintenance cost of highway bridges due to corrosion is estimated to be around $\$ 8.3$ billion in $2001^{1}$.

Bridge deterioration is caused by deicing salts that are used to keep the decks clear from ice and snow. The chloride ion contained in the deicing salts accelerates the corrosion of steel in concrete. The mechanisms of corrosion are explained later in detail in Chapter 2. Deicing salts carried by automobiles have resulted in severe damage to parking garages ${ }^{2}$. Deicing salt contamination in the garages is localized in the driving lanes. Structures exposed to seawater such as sea embankment are also subjected to chloride ion damage. The problem is more severe in terms of seawater exposure because of the availability of oxygen. 
Steel reinforced concrete is a mixture of cement, fine and coarse aggregates, additive like air entrainment chemicals, plasticizers and steel rebars. It is a versatile and economical construction material. Concrete usually contains high concentrations of soluble calcium, sodium and potassium oxides. This creates high alkaline conditions in concrete ( $\mathrm{pH}$ of $12-$ 13). Steel usually corrodes when exposed to water and air. But when steel is reinforcing concrete beams or columns, it forms a passive film on the surface due to the alkalinity of the cement paste in concrete. Passive film is a thick, adherent layer formed over steel surface to prevent corrosion. The passive film is made of gamma-ferric oxide which reduces corrosion, ideally by ten-fold. The presence of chlorides or reduction of $\mathrm{pH}$ breaks down the passive film on steel. The breakdown mechanism of passive film is still being studied. Many researchers have conflicting information regarding the behavior of passivity ${ }^{3}$. They are:

1. Chloride ions initiate breakdown of passive film by replacing its oxygen content.

2. The film itself may contain defects through which chloride ions penetrate, even without film breakdown.

3. Chemically induced mechanical disruption of the passive film.

The factors influencing corrosion of steel in concrete include alkalinity, permeability and resistivity. Corrosion of steel in concrete is an electrochemical process and is similar to that of corrosion of steel in aqueous solutions. Corrosion reaction occurs if chloride, oxygen and moisture reach the surface of the steel embedded in concrete. Corrosion is initiated in steel due to potential difference between two locations of the steel along its length. These 
potential differences occur due to variations in oxygen concentration, moisture content and $\mathrm{pH}$. If chloride ions are present, corrosion of steel becomes more severe.

\subsection{Objective and Scope}

The primary objective of this study is to determine the corrosion rates of the highchromium steel and conventional steel embedded in concrete in a chloride environment. Another objective of this study is to determine the corrosion rate of bare steel rebar and investigate why the corrosion rate of high-chromium steel is low in comparison with conventional steel. To accomplish these objectives concrete blocks reinforced with highchromium and conventional steel rebars were immersed in two different sodium chloride concentrations (1.7 and 3\%) with air bubbling into the solution. These concrete blocks were within drawn periodically and tested for its corrosion rate using 3-LP device. The chloride ion concentrations present in the concrete blocks were determined using chloride analysis method. Similarly, bare steel rebars were immersed in different sodium chloride concentrations $(0.1,0.5,1.7$ and $3 \%)$ with air bubbling into the solution. Corrosion rate was determined by weight loss of the rebars. Corrosion products were analyzed using chemical analysis, particle size distribution and X-ray diffraction to determine the characteristics of the corrosion products and to identify the minerals present in them.

\subsection{Report Organization}

- The review of available literature has been carried out and reported in chapter 2, with a general description on mechanism of corrosion of steel in concrete, protection techniques, characteristics of corrosion products, different corrosion monitoring techniques with emphasis on linear polarization resistance method. 
- Chapter 3 deals with experimental procedures and test setup for corrosion study.

- Chapter 4 provides the results and discussion of experimental data of all the tests conducted during this study

- Chapter 5 presents the conclusions derived from this study.

- Appendix provides the data for corrosion rate of high-chromium and conventional steel embedded in concrete. It also provides the data for corrosion rate of bare steel rebars. 


\section{Chapter 2}

\section{Literature Review}

Many studies have been developed to determine the corrosion rate of steel in concrete. The studies presented herein relate to corrosion of steel in concrete, corrosion product analysis and polarization resistance measurements. Additionally, the studies presented herein include factors influencing the corrosion of steel in concrete, mechanism of corrosion of steel in concrete, corrosion protection techniques and other available corrosion monitoring techniques used in industries.

Chloride induced corrosion in concrete occurs when concrete pores that are saturated with alkali solution carry the chlorides. The presence of alkaline solutions in pores increases the electrical conductivity of the concrete. The increase in conductivity enhances ion transfer between anode and cathode electrode. The process of carbonation needs a dry concrete for carbon dioxide to penetrate through the thickness of concrete. This carbonation also causes corrosion of steel rebar in concrete due to the well connected pore structure in concrete which allows rapid ingress of carbon dioxide. Then carbon dioxide reacts with alkaline solution resulting in decrease in $\mathrm{pH}$ for corrosion to initiate.

\subsection{Mechanism of Corrosion of Steel in Concrete}

The mechanism of corrosion of steel in concrete is two-fold. They are chloride attack

and carbonation ${ }^{4}$. These two mechanisms usually do not attack the integrity of concrete but they attack steel. However other ions such as sulfates attack the integrity of concrete before attacking steel. Carbonation occurs due to the interaction of carbon dioxide in the 
atmosphere with the alkaline hydroxides in the concrete forming carbonic acid. This carbonic acid further reacts with the pore solution (calcium hydroxide) in concrete to form calcium carbonate. Due to this reaction $\mathrm{pH}$ falls in the range suitable for corrosion of steel to occur. The carbonation occurs through the following reactions:

$\mathrm{CO}_{2}+\mathrm{H}_{2} \mathrm{O} \rightarrow \mathrm{H}_{2} \mathrm{CO}_{3}$

$\mathrm{H}_{2} \mathrm{CO}_{3} \rightarrow \mathrm{H}^{+}+\mathrm{HCO}_{3}^{-}$

$\mathrm{HCO}_{3}^{-} \rightarrow \mathrm{H}^{+}+\mathrm{CO}_{3}^{-}$

$\mathrm{H}_{2} \mathrm{CO}_{3}+\mathrm{Ca}(\mathrm{OH})_{2} \rightarrow \mathrm{CaCO}_{3}+2 \mathrm{H}_{2} \mathrm{O}$

Carbonation damage occurs rapidly if the steel is located shallow from the outer surface of the concrete. Even at high depths this effect occurs due to high water-cement ratios and poor curing. Carbonation is easily detected using the phenolphthalein indicator in solution of water and alcohol. If the color of the indicator is pink, the activity of carbonation is low. Phenolphthalein changes from colorless at low $\mathrm{pH}$ (carbonated zone) to pink at high $\mathrm{pH}$ (uncarbonated zone) ${ }^{4}$. Carbonation can be prevented by high cement-water ratios, good curing and enough cover depth of concrete.

Consider a basic mechanism of the corrosion reaction. At the anode the metal dissolves into the solution producing electrons. This process is called anodic reaction or oxidation reaction ${ }^{5}$.

$\mathrm{Fe}=\mathrm{Fe}^{2+}+2 \mathrm{e}^{-}$

At the cathode, the dissolved oxygen in the pore water is reduced by consuming the electrons supplied by the anode reaction.

$\mathrm{O}_{2}+2 \mathrm{H}_{2} \mathrm{O}+4 \mathrm{e}^{-}=4 \mathrm{OH}^{-}$ 
The rate of these reactions depends upon temperature, moisture content, ion concentration and permeability of the concrete. The presence of chlorides in sufficient concentration at the steel concrete interface results in the break down of the passive film ${ }^{4}$. The depassivation mechanism for chloride attack differs from carbonation. The chloride ions act as a catalyst for depassivation. In the absence of chloride, the passive film dissolves slowly as ferric ions. The $\mathrm{FeOOH}$ is a hydrated passive film, with iron in the ferric oxidation state ${ }^{6}$. Chlorides catalyze the dissolution of this ferric hydroxide shown:

$\mathrm{FeOOH}+\mathrm{Cl}^{-} \rightarrow \mathrm{FeOCl}+\mathrm{OH}^{-}$

$\mathrm{FeOCl}+\mathrm{H}_{2} \mathrm{O} \rightarrow \mathrm{Fe}^{3+}+\mathrm{Cl}^{-}+2 \mathrm{OH}^{-}$

The reactions (7) and (8) destroy the passive film at the steel surface and anodic dissolution of Fe at the bare site follows. Then ferrous ions are produced and react with chlorides to form ferrous chloride.

$\mathrm{Fe}^{2+}+2 \mathrm{Cl}^{-} \rightarrow \mathrm{FeCl}_{2}$

The ferrous chloride reacts with water and the hydroxyl ions in the pore water to form ferrous hydroxide forming a greenish black product at the anodic sites. Chloride ions are simultaneously released into the pore water. Then the chloride ions further reacts with ferrous ions to continue the corrosion process in a cycle.

$\mathrm{FeCl}_{2}+2 \mathrm{H}_{2} \mathrm{O}=\mathrm{Fe}(\mathrm{OH})_{2}+2 \mathrm{H}^{+}+2 \mathrm{Cl}^{-}$

The ferrous hydroxide react with oxygen and pore water to form ferric hydroxide which is then dissociated into ferric oxide, a reddish brown rust product.

$$
\begin{aligned}
& \mathrm{Fe}(\mathrm{OH})_{2}+1 / 2 \mathrm{O}_{2}+\mathrm{H}_{2} \mathrm{O} \rightarrow 2 \mathrm{Fe}(\mathrm{OH})_{3} \\
& 2 \mathrm{Fe}(\mathrm{OH})_{3} \rightarrow \mathrm{Fe}_{2} \mathrm{O}_{3}+3 \mathrm{H}_{2} \mathrm{O}
\end{aligned}
$$


The threshold concentration of chloride ions from the previous researches is assumed to be $0.2 \%$ to $0.4 \%$ chloride ion by weight of cement ${ }^{4}$. This concentration is the minimum concentration of free chloride ions which causes a significant level of steel rebar corrosion.

\subsection{Factors Influencing Corrosion of Steel in Concrete}

The major factors influencing corrosion of steel in concrete were discussed.

- Permeability of Concrete

The permeability of concrete is a major factor affecting the corrosion of reinforcing steel. Concrete of low permeability contains less water and likely to have low-conductivity and better resistance to corrosion. It resists the absorption of deicing salts and their penetration to the reinforcing steel, as well as provides a barrier against the entry of oxygen. Low water-cement ratios tend to produce concrete of lower permeability and thus provide greater resistance against concrete.

\section{- Alkalinity of Concrete}

The interaction of carbon dioxide in the atmosphere with alkaline solution in the concrete pores increases $\mathrm{pH}$ and decreases alkalinity, and initiating corrosion to occur. Due to aging of a structure, moisture present in the concrete will be lost, which results in shrinkage. Corrosion of structures that are not exposed to outside atmosphere depends on the amount of moisture in air which is measured in terms of relative humidity. The effect of relative humidity was discussed in Chapter 4.

- Concrete Resistivity

The resistivity of concrete is dependent upon the moisture content of the concrete.

Dry concrete is found to have high resistivity, $1 \times 10^{9} \Omega$-cm, and water saturated concrete has 
been found to have a resistivity, $1 \times 10^{4} \Omega$-cm. Thus, in dry concrete, corrosion rate is low due to the lack of electrolyte. However, the corrosion rate in water saturated concrete is high due to increased content of electrolyte in the pores. The addition of certain materials to concrete such as silica fills the pores, increases resistivity and lowers corrosion rate, due to the increased resistance to ionic conduction ${ }^{4}$.

\subsection{Corrosion Protection Techniques}

Several methods have been employed in practice to protect and rehabiliate existing structures. These methods are: cathodic protection (CP), electro-chemical chloride extraction, realkalization and others.

\section{- Cathodic Protection (CP)}

There are two types of cathodic protection which include impressed current system and sacrificial anode system. Impressed current cathodic protection works by passing a small direct current from anode to the reinforcing steel. For chloride-contaminated concrete bridge decks, impressed-current cathodic protection using titanium mesh anodes provides a good solution to the reinforcing steel corrosion. However, it is very important to properly maintain the rectifiers and electrical wiring. In sacrificial anode system, the anodes such as zinc, aluminum and magnesium were used without power supply. The main disadvantage of sacrificial anode system is the driving voltage.

\section{- Electro-chemical Chloride Extraction}

Electrochemical chloride extraction is an alternative rehabilitation method to counter steel corrosion in contaminated concrete. This method can be accomplished by passing direct current between the anode and reinforcing steel. The chloride ions move towards the anode and at the same time hydroxyl ions are produced around the rebar. Although, this 
method is less permanent, it has the advantage of having no rectifier or wiring to maintain after the treatment.

- Realkalization

When concrete ( $\mathrm{pH} 12$ to 13 ) looses its alkalinity to a certain threshold level due to the action of carbon dioxide from air, corrosion of steel will proceed at a faster rate. The anodes were used to remove chlorides; additionally sodium carbonate electrolyte was used to

prevent further carbonation. Hence, concrete is typically realkalized through electrochemical process to its original $\mathrm{pH}$ level to suppress further corrosion.

\subsection{Characteristics of Corrosion Products on Steel Rebars}

The chemical characterization of the oxide layer formed on steels and the understanding of its formation mechanisms are important factors for the development and improvement of its corrosion resistance. Corrosion rates are primarily dependent on the environmental conditions to which the steel is subjected to. Even the formation of oxide films and their transformation from one phase to another primarily depends on the environment. There is plenty of literature available on the study of characterization of corrosion products formed on the steels ${ }^{6}$. Most common phases found on the steel were lepidocrocite $(\gamma-\mathrm{FeOOH})$, goethite $(\alpha-\mathrm{FeOOH})$ and magnetite $\left(\mathrm{Fe}_{3} \mathrm{O}_{4}\right)$. Lepidocrocite appears like small crystalline globules or fine plates; goethite looks likes globular structures called cotton balls which are interconnected by the formation as nests or even like acicular structures; and magnetite comes out as dark flat regions, with circular disks. Lepidocrocite is usually formed during the early stages of atmospheric corrosion but as the exposure time increases it transforms into goethite. 
The steel rebars exposed to long wet periods promote the formation of magnetite in weathering steels. However, during alternative wetting and drying cycles maghemite will be formed due to oxidation of magnetite ${ }^{7}$. This environment prevents the formation of lepidocrocite and goethite which is required for the formation of adherent passive layers in weathering steels. Corrosion products are usually larger in size than the microstructure of maghemite. The size of the corrosion product is in the range of $30-50 \mu \mathrm{m}$ while the microstructure sizes are in the range of $10-15 \mathrm{~nm}$.

\subsection{Need for Corrosion Monitoring}

The rate of corrosion provides information regarding the corrosive conditions of the environment. From the corrosion measurement data the remedial action can be taken for the most effective prevention of corrosion. Corrosion monitoring techniques provide early warning that damaging process conditions exist, which may result in corrosion induced failure and also diagnose a particular corrosion problems by identifying its cause in terms of parameters such as pressure, temperature, $\mathrm{pH}$, flow rate etc ${ }^{8}$.

\subsection{Corrosion Monitoring Techniques}

The following techniques are most commonly used ${ }^{8}$ :

- Corrosion Coupons (weight loss measurements)

Corrosion coupon testing is an in-line monitoring technique; coupons are placed directly in the process stream and extracted for measurement. This monitoring technique provides a direct measurement of metal loss that allows us to calculate the general corrosion rate.

- Electrical Resistance 
Electrical resistance probes utilize a relatively simple principle of an increase in electrical resistance produced by a decrease in the section thickness of a metallic conductor. The reference element is placed within the probe body and the measurement of the resistance ratio of the exposed to reference element is made. This method can be used in a wide range of environments and can be considered for low conductivity and non-aqueous conditions, where electrochemical techniques are generally unsuitable.

\section{- Linear Polarization Resistance}

It measures the DC current through the metal/fluid interface when the electrodes are polarized by a small electrical potential. As this current is related to the corrosion current that in turn is directly proportional to corrosion rate, the method provides an instantaneous measurement of corrosion rate. This has advantages over metal loss methods, but is limited in the scope of its application by the requirement that the fluid is conductive, which in practice limits it to aqueous solutions.

\section{- Galvanic Potential}

The galvanic monitoring technique use two electrodes of dissimilar metals and are exposed to the corrosive environment. When immersed in solution, a potential difference exits between the electrodes. The current generated due to this potential difference relates to the rate of corrosion which is occurring on the active of the electrode couple. 
- Hydrogen Penetration

This method actually measures the penetration current set up by the hydrogen as it moves through the steel. Its use is limited to hydrogen embrittlement environments.

- Microbial

Microbial monitoring identifies the presence of sulfate reducing bacteria (SRB). SRB is an anaerobic bacteria which consumes sulfate and generates sulfuric acid which attacks the production plant materials.

Among these techniques, weight loss measurements, electrical resistance and linear polarization resistance are mostly used due to the following advantages:

- Techniques are easy to implement.

- Equipment reliability has been demonstrated in the field environment over the years.

- Results are easy to interpret.

- Measuring equipment is safe for hazardous area operations.

\subsection{Linear Polarization Resistance Method}

The electrochemical technique, commonly referred to as Linear Polarization Resistance (LPR), is the only corrosion monitoring method that allows corrosion rates to be measured directly. This technique is limited to electrolytically conducting liquids but its response time and data quality makes this technique superior to other corrosion monitoring techniques ${ }^{8}$. There are varieties of methods capable of determining instantaneous polarization resistances such as potential step, current step, impedance spectroscopy as well as statistical and noise methods. All of these methods use two, three or four electrode 
electrochemical cells. Instantaneous corrosion rate information can be obtained from such relatively rapid electrochemical measurements in short time periods.

\subsection{Theory of Linear Polarization}

Linear polarization is a technique used to measure the corrosion rate of steel reinforced concrete. This technique measures the response of a system to a small electrical perturbation to calculate the polarization resistance. The polarization resistance is subsequently converted into corrosion rate by applying the Stern-Geary equation ${ }^{9}$.

$I_{\text {corr }}=\frac{\Delta I_{a p p}\left(\beta_{a} \times \beta_{c}\right)}{2.3 \Delta \varphi\left(\beta_{a}+\beta_{c}\right)}$

where $\mathrm{I}_{\text {corr }}=$ corrosion current in $\mathrm{mA}$

$\Delta \mathrm{I}_{\text {app }}=$ direct current required to cathodically polarize the rebar

$\Delta \varphi=$ absolute value of cathodic polarization potential minus natural half-cell

$\beta_{\mathrm{a}}=$ anodic Tafel slope

$\beta_{\mathrm{c}}=$ cathodic Tafel slope

The underlying theory of this equation is for small values of potential change of $\Delta \varphi$ such as less than $12 \mathrm{mV}$, a linear relationship established between this change of potential $\Delta \varphi$ and change of current $\Delta \mathrm{I}_{\text {app. }}$. The experimental work pertains to the measurement of $\Delta \mathrm{I}_{\text {app }}$ versus $\Delta \varphi$, from which the linear relationship or the slope of the straight line is obtained, and thus $\mathrm{I}_{\text {corr }}$ can be determined ${ }^{10}$.

\subsection{Limitations of Polarization Resistance Measurements}

- The Stern-Geary relationship is valid only for activation controlled process. 
- This method is applicable under the special Non-Tafel conditions of $\beta_{\mathrm{a}}$ or $\beta_{\mathrm{c}}=\alpha$ corresponding to passivity or cathodic diffusion limiting current densities respectively.

- Values of $\beta_{\mathrm{a}}$ and $\beta_{\mathrm{c}}$ may change during measurement and may be even different at the corrosion potential from those values determined at large overpotentials i.e., under Tafel conditions.

- The corrosion rate $\mathrm{i}_{\text {corr }}$, must be much larger than any other exchange currents of redox reactions or the latter rates will dominate the polarization resistance measurement.

- Resistances from the presence of films on the electrodes and the electrolyte resistance between the working and reference electrode in high resistivity media can produce an underestimation of corrosion rates due to IR losses on $\Delta \mathrm{E}$ and must be compensated to obtain accurate measurements.

- The method measures general corrosion, but is not a reliable measure of localized corrosion including pitting, crevice or stress corrosion cracking, though unsteady measurements may indicate intermittent reactions of these types.

There are many instruments available to measure the corrosion rate using linear polarization theory. One example is the 3-LP device invented by Kenneth C. Clear Company. The 3-LP device uses the values of $\beta_{\mathrm{a}}$ and $\beta_{\mathrm{c}}$ as $150 \mathrm{mV}$ and $250 \mathrm{mV}$, respectively for steel in concrete. Then, the corrosion current density $\left(\mathrm{mA} / \mathrm{m}^{2}\right)$ will be given as 


$$
i_{\text {corr }}=\frac{40.76 \times S}{\pi \times B \times K}
$$

where $\mathrm{K}=$ rebar length beneath counter electrode in $\mathrm{m}$

$$
\begin{aligned}
& \mathrm{B}=\text { rebar diameter beneath the counter electrode in } \mathrm{m} \\
& \mathrm{S}=\Delta \mathrm{I} / \Delta \varphi(\mathrm{mA} / \mathrm{mV})
\end{aligned}
$$

Table 1 provides the guidelines to interpret data obtained with the 3-LP device.

Table 1 Relationship between corrosion rate and possible damage in years

\begin{tabular}{|l|l|}
\hline $\mathrm{i}_{\text {corr }}<2.2 \mathrm{~mA} / \mathrm{m}^{2}$ & no corrosion \\
$\mathrm{i}_{\text {corr }}$ between 2.2 and $10.8 \mathrm{~mA} / \mathrm{m}^{2}$ & $\begin{array}{l}\text { corrosion damage possible in the } \\
\text { range of } 10 \text { to } 15 \text { years } \\
\mathrm{i}_{\text {corr }} \text { between } 10.8 \text { and } 108 \mathrm{~mA} / \mathrm{m}^{2}\end{array}$ \\
$\mathrm{i}_{\text {corr }}$ more than $108 \mathrm{~mA} / \mathrm{ft}^{2}$ & $\begin{array}{l}\text { corrosion damage expected in } 2 \text { to } 10 \text { years } \\
\text { corrosion damage expected in } 2 \text { years or less }\end{array}$ \\
\hline
\end{tabular}




\section{Chapter 3}

\section{Experimental Procedures}

The purpose of this chapter is to describe the test specimen preparation and the various test methods used for this study. The materials used for this study were highchromium steel, conventional steel and concrete. Concrete blocks reinforced with highchromium and conventional steels were placed in sodium chloride solutions and allowed to corrode. Corrosion rates were measured at regular time intervals using 3-LP device. The concrete blocks were then analyzed for chloride ion concentration. Bare steel rebars were also placed in sodium chloride solution and corroded. The bare steel rebars were withdrawn periodically and the corrosion products were removed. Corrosion rates were determined by weight loss of rebars. The corrosion products were analyzed using chemical analysis, particle size distribution analysis and X-ray diffraction analysis to study their characteristics and to identify the minerals present in them.

\subsection{Material Selection}

\section{High-Chromium (HC) and Conventional Steel Rebars}

A new type of high strength corrosion resistant steel reinforcements using nanotechnology has been evaluated herein. Its inherent corrosion resistance and high strength are due to the unique microstructure as opposed to conventional steels. This steel contains high-chromium content (up to $11 \%$ ) and is thus corrosion resistant because chromium provides a wide range of passivity in terms of potential and $\mathrm{pH}$ like stainless steels. It is claimed that this high-chromium steel has a unique microstructure which is 
formed during hot rolling, and greatly helps this steel to reduce its corrosion rate ${ }^{12}$. In addition to its excellent corrosion resistance, this steel possesses good mechanical properties such as higher strength, energy absorption, toughness, brittleness, and ductility compared with conventional steels. The chemical composition of high-chromium steel and conventional steel used in this study are shown in Tables 2 and 3, respectively.

Table 2 Chemical constituents of high-chromium steel (wt \%) ${ }^{12}$

\begin{tabular}{|l|l|l|l|l|l|l|l|}
\hline Element & Carbon & Chromium & Manganese & Nitrogen & Phosphorus & Sulfur & Silicon \\
\hline Amount & $0.10 \%$ & $9 \%$ & $1.5 \%$ & $400 \mathrm{ppm}$ & $0.02 \%$ & $0.025 \%$ & $0.50 \%$ \\
\hline
\end{tabular}

Table 3 Chemical constituents of conventional steel (wt \%)

\begin{tabular}{|l|l|l|l|l|l|l|l|l|l|l|}
\hline Element & $\mathrm{C}$ & $\mathrm{Mn}$ & $\mathrm{P}$ & $\mathrm{S}$ & $\mathrm{Si}$ & $\mathrm{Cu}$ & $\mathrm{Cr}$ & $\mathrm{Mo}$ & $\mathrm{Ni}$ & $\mathrm{Sn}$ \\
\hline Amount & $.12 \%$ & $.95 \%$ & $.019 \%$ & $.050 \%$ & $.18 \%$ & $.41 \%$ & $.15 \%$ & $.04 \%$ & $.15 \%$ & $.018 \%$ \\
\hline
\end{tabular}

Figure 1 shows the stress-strain curves of high-chromium and conventional steels.

From this figure we can see that the high-chromium steel possesses higher yield and ultimate strength than conventional steel. The yield and ultimate tensile strength of high-chromium steel was found to be $827.36 \mathrm{~N} / \mathrm{mm}^{2}$ and $1220.35 \mathrm{~N} / \mathrm{mm}^{2}$. In conventional steel, the yield and ultimate tensile strength was found to be $484.70 \mathrm{~N} / \mathrm{mm}^{2}$ and $750.15 \mathrm{~N} / \mathrm{mm}^{2}$. The higher yield strength of high-chromium steel allows the material to carry higher loads without plastic deformation. Due to its high strength the rebar requirements in terms of number density in concrete can be reduced and thus significantly reduces costs. 


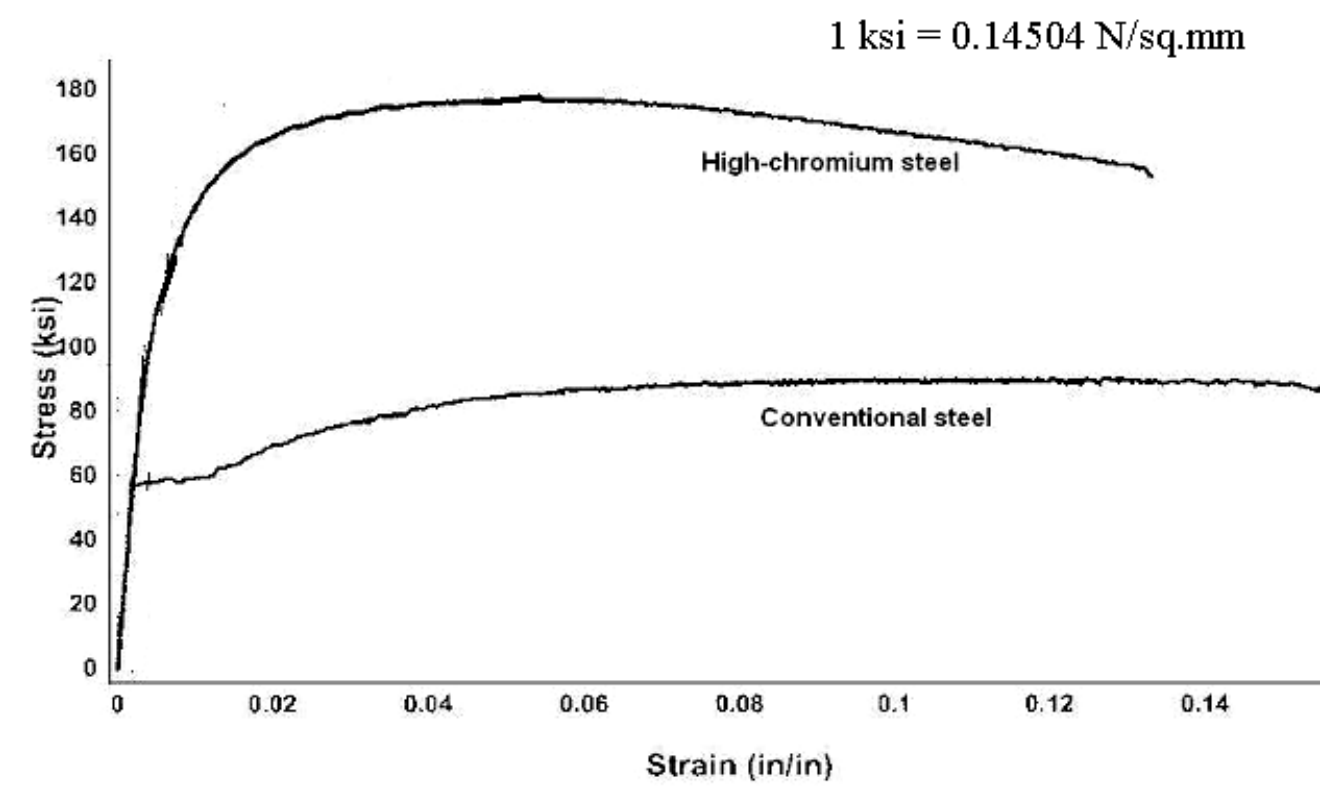

Figure 1: Stress-strain curves for high-chromium and conventional steel rebars ${ }^{12}$

\section{Concrete}

Concrete is the synthetic material produced when cement is mixed with fine aggregates, coarse aggregates, and water. Also, admixtures are added to conventional concrete mix to enhance its durability. There are five different types of Portland cement and their difference is due to the proportioning of the anhydrous mineral constituents such as tricalcium silicate, dicalcium silicate, tricalcium aluminate, etc., and they are also classified according to the fineness of the ground product. Type 1 cement is the most common type of Portland cement and it is used for making concrete in this study. The typical proportions of primary anhydrous material present in Type 1 cement are as follows ${ }^{13}$ : 
Table 4 Proportions of primary anhydrous mineral phases in Type 1 Portland cement (wt \%)

\begin{tabular}{|l|l|}
\hline Tricalcium Silicate & $51 \%$ \\
Dicalcium Silicate & $25 \%$ \\
Tricalcium Aluminate & $9 \%$ \\
Tetracalcium Aluminoferrite & $8 \%$ \\
Other phases & $7 \%$ \\
\hline
\end{tabular}

Aggregates are used in the production of concrete. Both fine and coarse aggregates are used to control the mechanical properties and characteristics of concrete. They are chosen based on the ASTM C33-03 requirements. Additionally, admixtures are used which are organic or inorganic materials added to concrete immediately before or during mixing to modify the properties of fresh or hardened concrete ${ }^{13}$. Admixtures include air-entraining, water reducing, set retarding, set-accelerating and finely powdered minerals. The design of concrete mix depends upon the application which includes economics, workability, strength and durability. Table 5 shows the mix design of concrete used in the making of the concrete block in the study.

Table 5 Mix volume and volume proportions of concrete used

\begin{tabular}{|l|l|}
\hline Concrete Constituents & Volume (\%) \\
\hline Cement (Type 1) & 10.63 \\
\hline Aggregates & \\
Greer 57 Limestone & 20.88 \\
Stocker Sand & 25.87 \\
Greer 67 Limestone & 20.88 \\
\hline Water & 15.74 \\
\hline Total Air Content & 6.00 \\
\hline Total & 100 \\
\hline
\end{tabular}


Theoretical Unit Weight $=2297.05 \mathrm{Kg} / \mathrm{m}^{3}$

Water $/$ Cement Ratio $=0.47$

Compressive Strength 7 days $=31.03 \mathrm{~N} / \mathrm{mm}^{2}, 28$ days $=37.86 \mathrm{~N} / \mathrm{mm}^{2}$

\subsection{Test Specimen Preparation}

Concrete blocks were made by reinforcing with high-chromium and conventional

steels. The concrete blocks were coated with epoxy to prevent the ingress of chloride ions on two sides as shown in Figure 2. Twelve concrete blocks were made for this study. To analyze the chloride ion content in the concrete block, about $0.0125 \mathrm{~m}$ hole was drilled in the center of the concrete block (till the steel concrete interface). Table 6 shows the test matrix for concrete blocks reinforced with steel.

Two-inch steel pieces of high-chromium as well as conventional steels were used for bare steel rebar study as shown in Figure 3. The corrosion products were collected and dried. Then, it was analyzed using chemical analysis, particle size distribution and X-ray diffraction. Table 7 shows the test matrix of bare steel rebar study. 


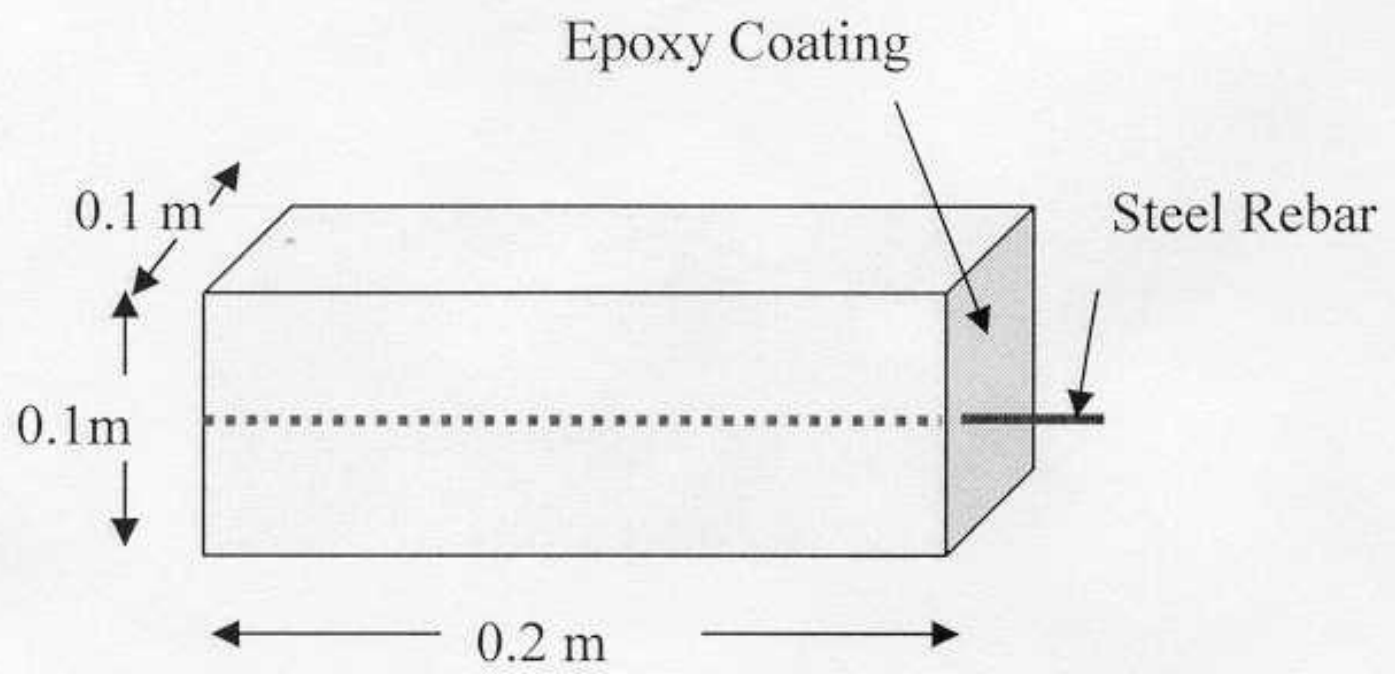

Figure 2: Concrete blocks coated with epoxy on two sides

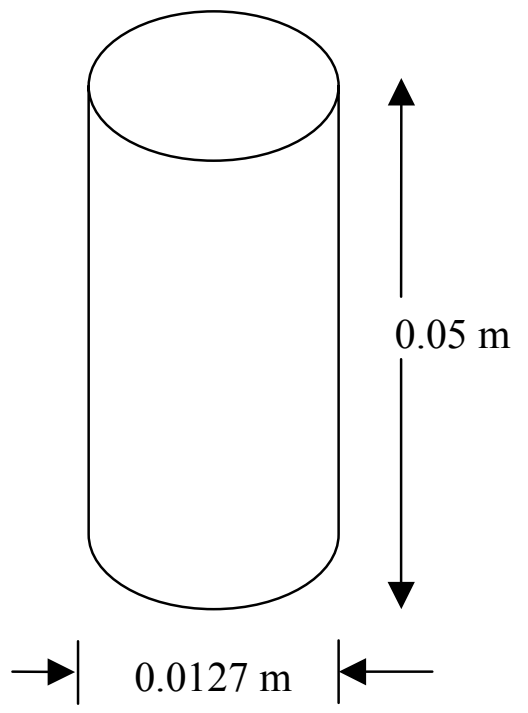

Figure 3: Dimensions of steel rebars 
Table 6 Test matrix for concrete blocks reinforced with steel

\begin{tabular}{|l|l|l|}
\hline $\begin{array}{l}\text { Type of steel } \\
\text { rebars used } \\
\text { in concrete }\end{array}$ & $\begin{array}{l}\text { Sample numbers and sodium } \\
\text { chloride concentrations }\end{array}$ \\
\cline { 2 - 3 } & $\mathbf{1 . 7 \%}$ & $\mathbf{3 . 0} \%$ \\
\hline $\mathrm{HC}$ & 1 & 7 \\
& 2 & 8 \\
& 3 & 9 \\
\hline $\mathrm{CV}$ & 4 & 10 \\
& 5 & 11 \\
& 6 & 12 \\
\hline
\end{tabular}

Table 7 Test matrix for bare steel rebars study

\begin{tabular}{|l|l|l|l|l|}
\hline \multirow{2}{*}{$\begin{array}{l}\text { Type of steel } \\
\text { rebar }\end{array}$} & \multicolumn{4}{|l|}{ Sample numbers and sodium chloride concentrations } \\
\cline { 2 - 5 } & $\mathbf{0 . 1 \%}$ & $\mathbf{0 . 5 \%}$ & $\mathbf{1 . 7 \%}$ & $\mathbf{3 . 0 \%}$ \\
\hline $\mathrm{HC}$ & $\mathrm{a}, \mathrm{b}, \mathrm{c}$ & $\mathrm{g}, \mathrm{h}, \mathrm{i}$ & $\mathrm{m}, \mathrm{n}, \mathrm{o}$ & $\mathrm{s}, \mathrm{t}, \mathrm{u}$ \\
\hline $\mathrm{CV}$ & $\mathrm{d}, \mathrm{e}, \mathrm{f}$ & $\mathrm{j}, \mathrm{k}, \mathrm{l}$ & $\mathrm{p}, \mathrm{q}, \mathrm{r}$ & $\mathrm{v}, \mathrm{w}, \mathrm{x}$ \\
\hline
\end{tabular}

\subsection{Corrosion Study of Concrete Blocks}

In this study, twelve blocks of concrete were cast using six rebars of conventional (CV) steel and six rebars of high-chromium (HC) steel. Then the blocks were cured for 28 days. Each block was $0.2 \mathrm{~m}$ long and $0.1 \times 0.1 \mathrm{~m}$ base or top. Both ends of the base of the concrete block were coated with epoxy resin to prevent chloride diffusion through the ends. This means that the chloride ions can reach the steel concrete interface by diffusion only through the four sides of the concrete. Two blocks of each HC steel and CV steel were placed in a 5-gallon plastic bucket containing 9.5 liters of a sodium chloride solution of $1.7 \%$ 
concentration. Air was bubbled through the solution using a disperser at $5.3 \mathrm{ml} / \mathrm{sec}$. The concrete blocks were rotated regularly every day to have equal exposure to the bubbling air and distilled water was added to compensate for a loss of solution due to evaporation. Two more buckets of the same size were used for remaining concrete blocks reinforced with $\mathrm{HC}$ and CV steels under the same conditions. These blocks were withdrawn at 32, 72 and 132 days and tested using the 3-LP device to measure the corrosion rate. Similar procedures are carried out using different set of concrete blocks in 3\% sodium chloride concentrations.

Figure 4 shows the schematic layout of galvanic circuit used for corrosion rate measurements. Figure 5 shows anodic and cathodic Tafel slopes. Figures 6 and 7 depict the experimental setup. Tests were performed using three electrodes. The steel bar was the cathode or the working electrode. The reference electrode of copper-copper sulfate was used to measure the potential changes induced by change of current which flowed from the anode (sponge) to the cathode (rebar). This method is based on linear polarization resistance method. The change of potential is plotted against the change of current. The slope of this plot is linear polarization resistance and can be translated into corrosion rate of the rebar in the concrete. Figure 8 shows a view of the 3 -LP device.

Figure 9 shows the anode, cathode and reference electrode for 3-LP device. The sponge of anode or counter electrode ( $0.2 \mathrm{~m}$ long $\mathrm{x} 0.1 \mathrm{~m}$ wide $\mathrm{x} 0.025 \mathrm{~m}$ thick) was wetted with a 5\% detergent solution. Then the anode was placed in parallel to the bar orientation. Proper care should be taken to make sure there is good contact of the sponge with the concrete surface. This is accomplished by adding weights on both ends of the sponge with 500 grams each. 


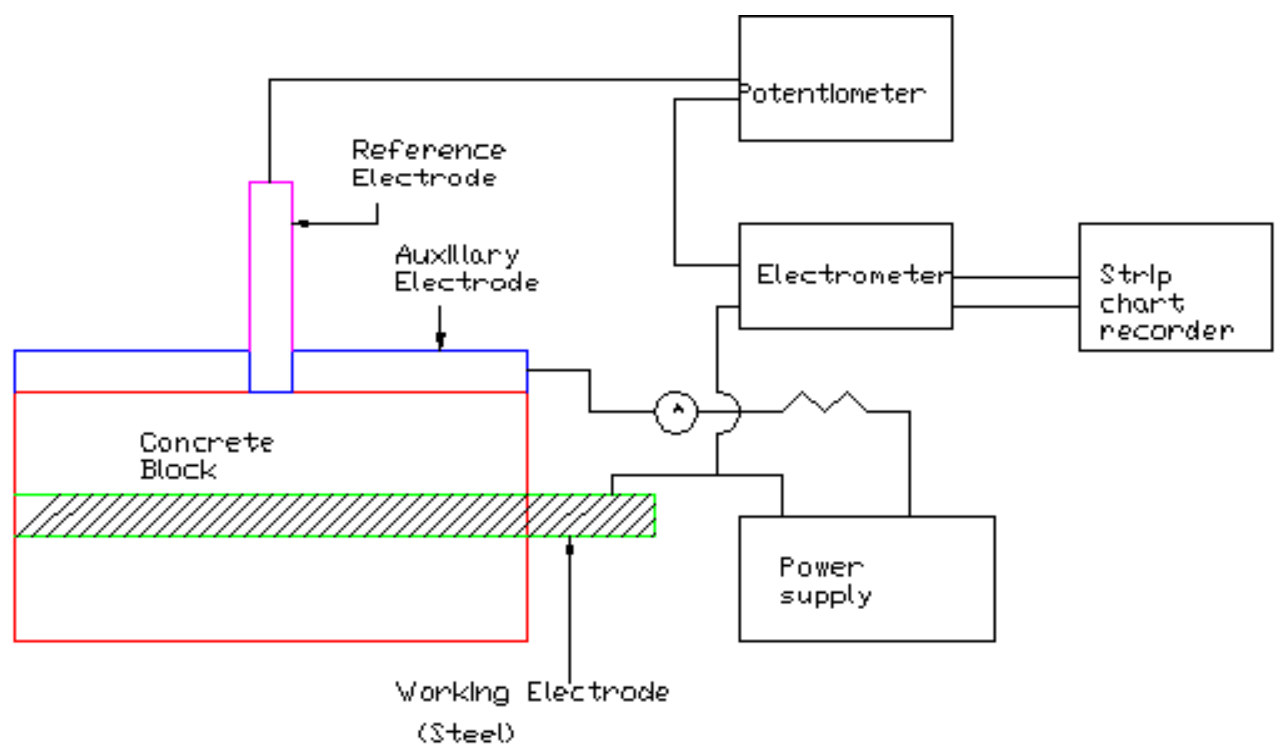

Figure 4: Galvanostatic circuit for corrosion rate measurements

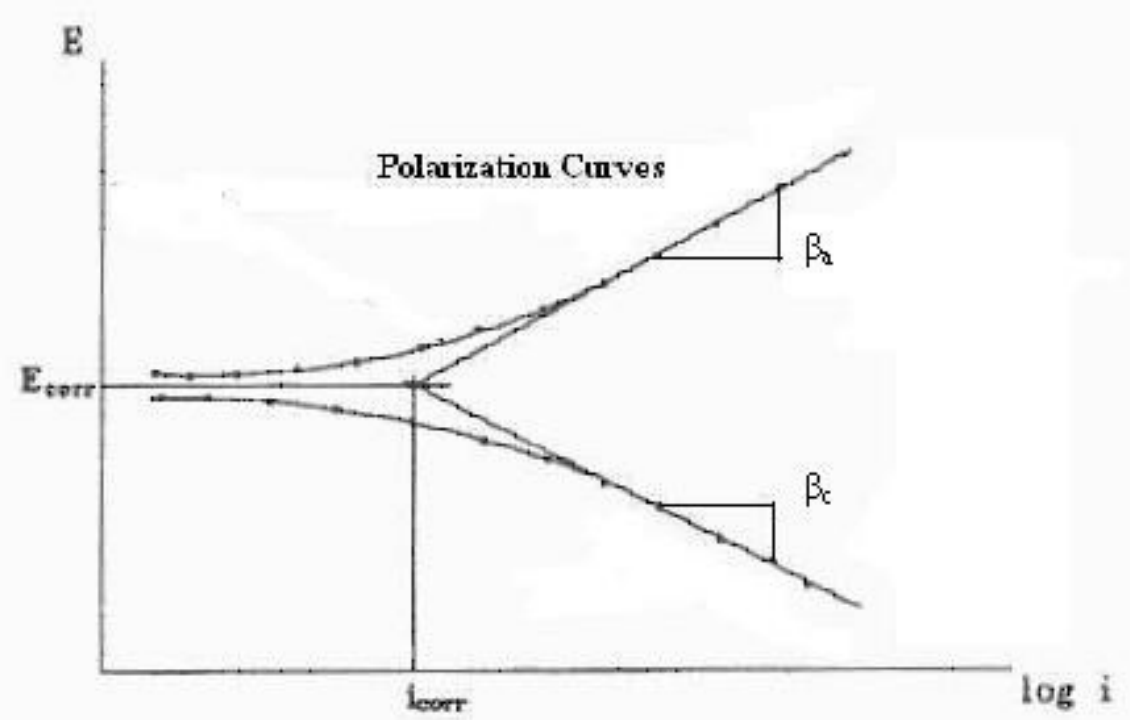

Figure 5: Typical polarization curves showing anodic and cathodic Tafel slopes 


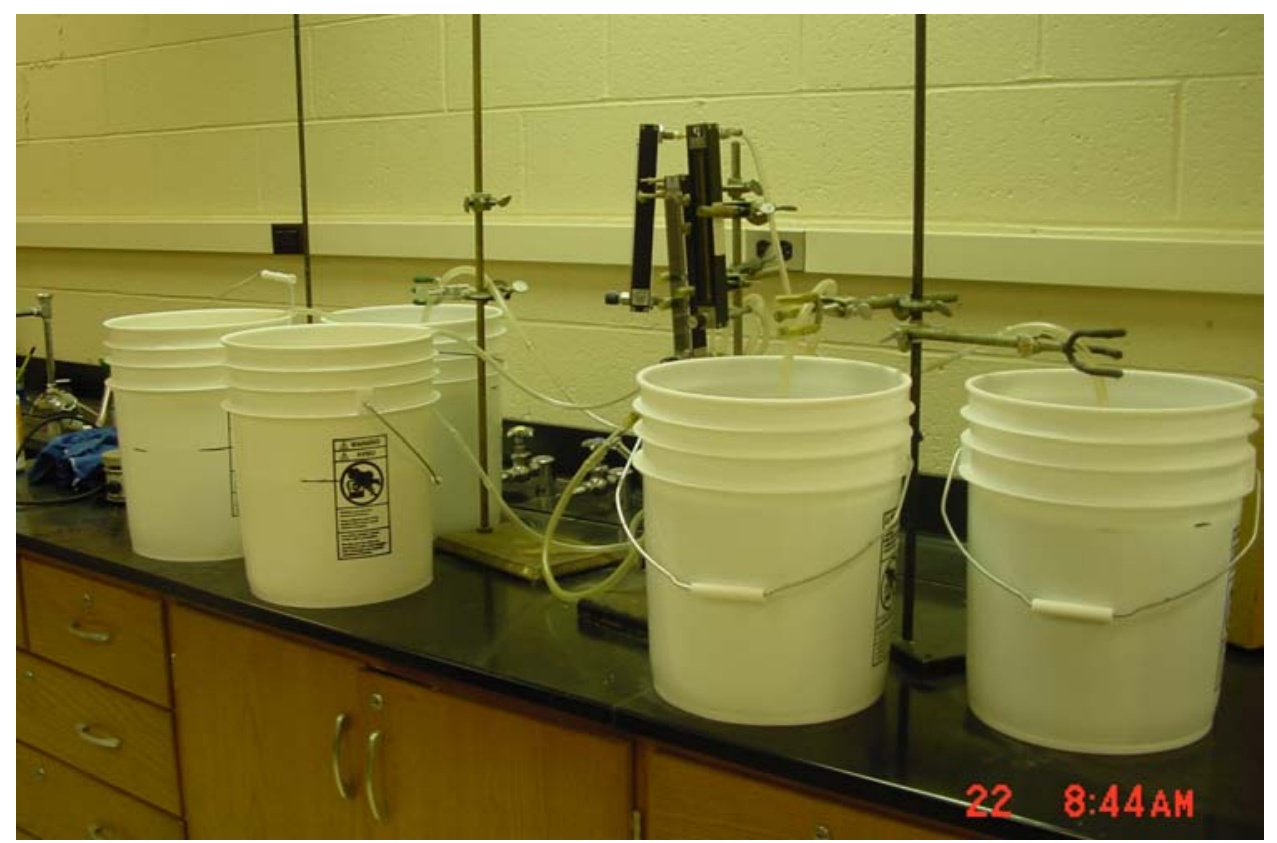

Figure 6: Experimental set up of concrete blocks immersed in sodium chloride solution

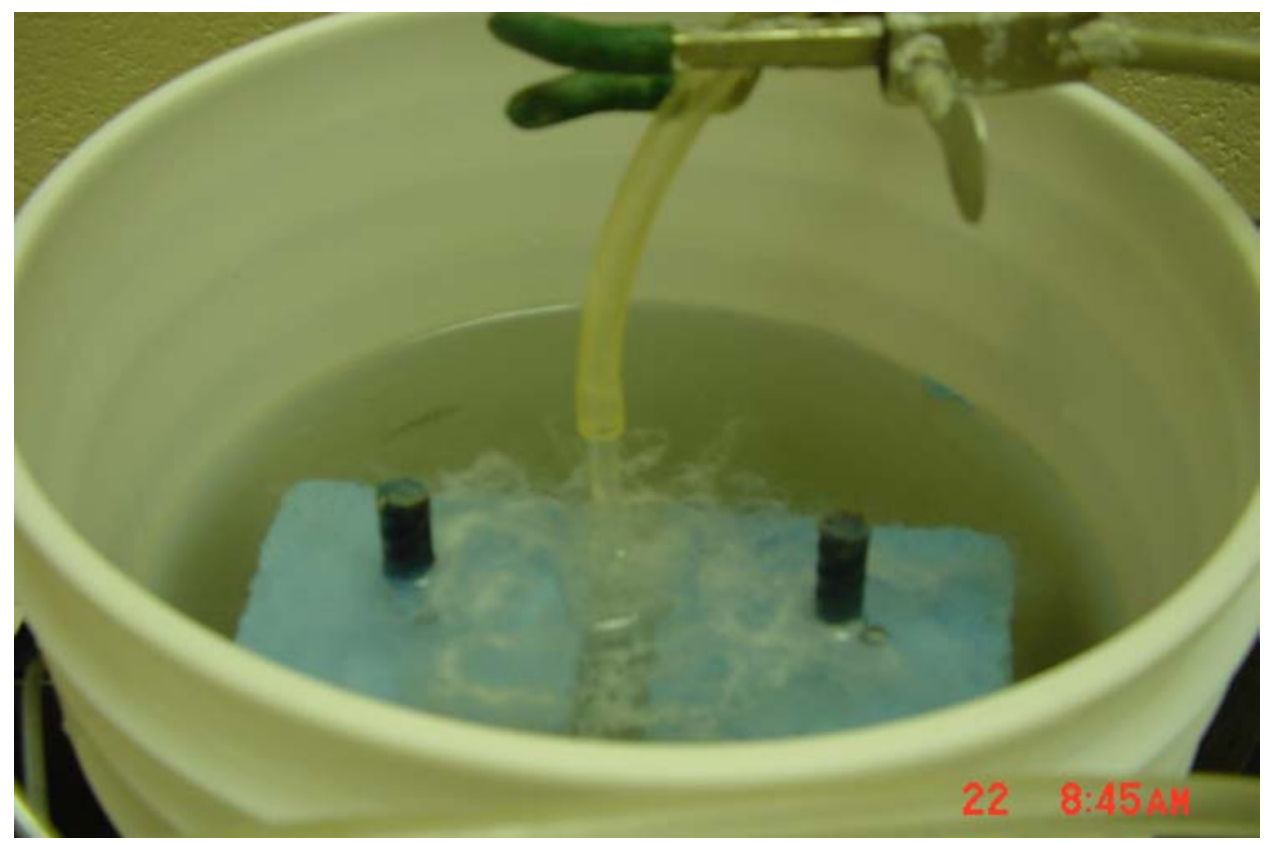

Figure 7: Air bubbling through the sodium chloride solution in between the concrete blocks 


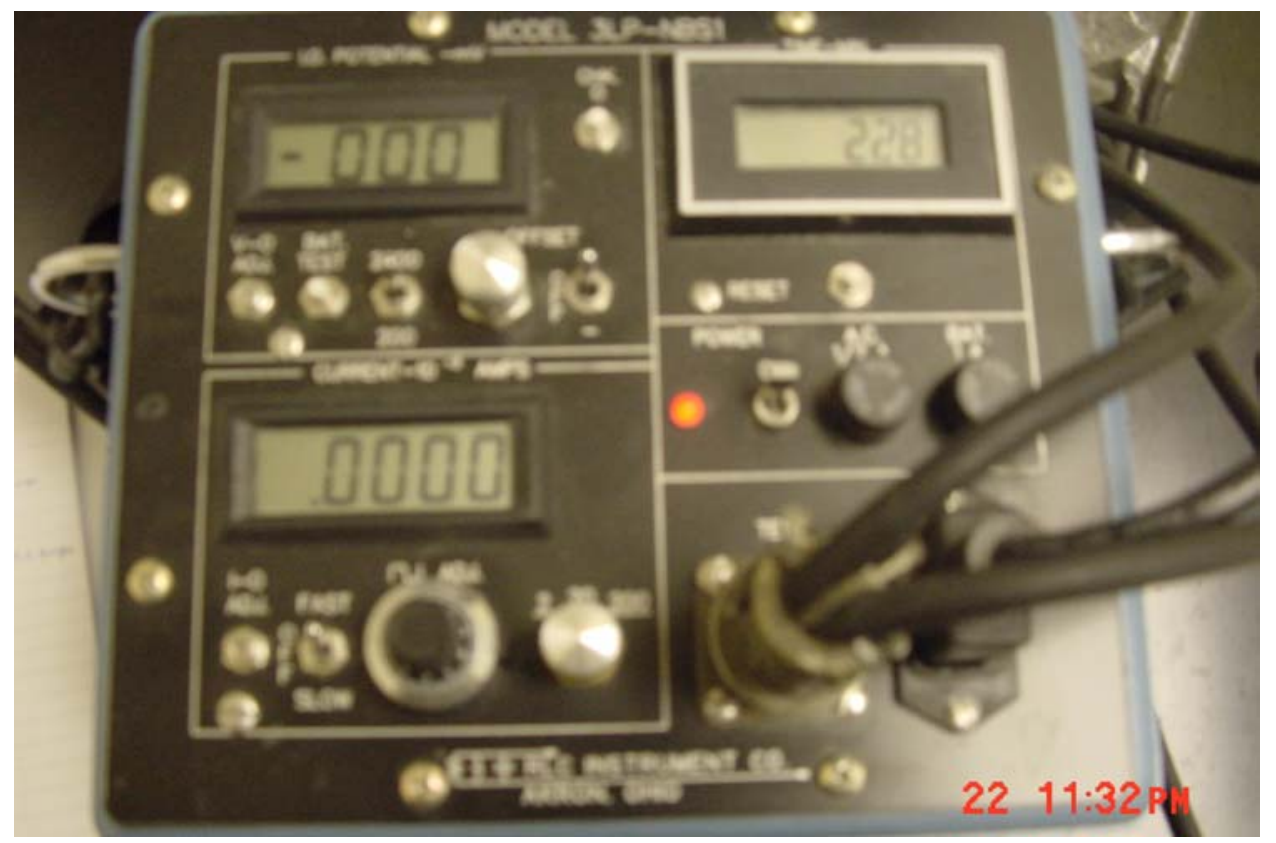

Figure 8: View of the 3-LP device

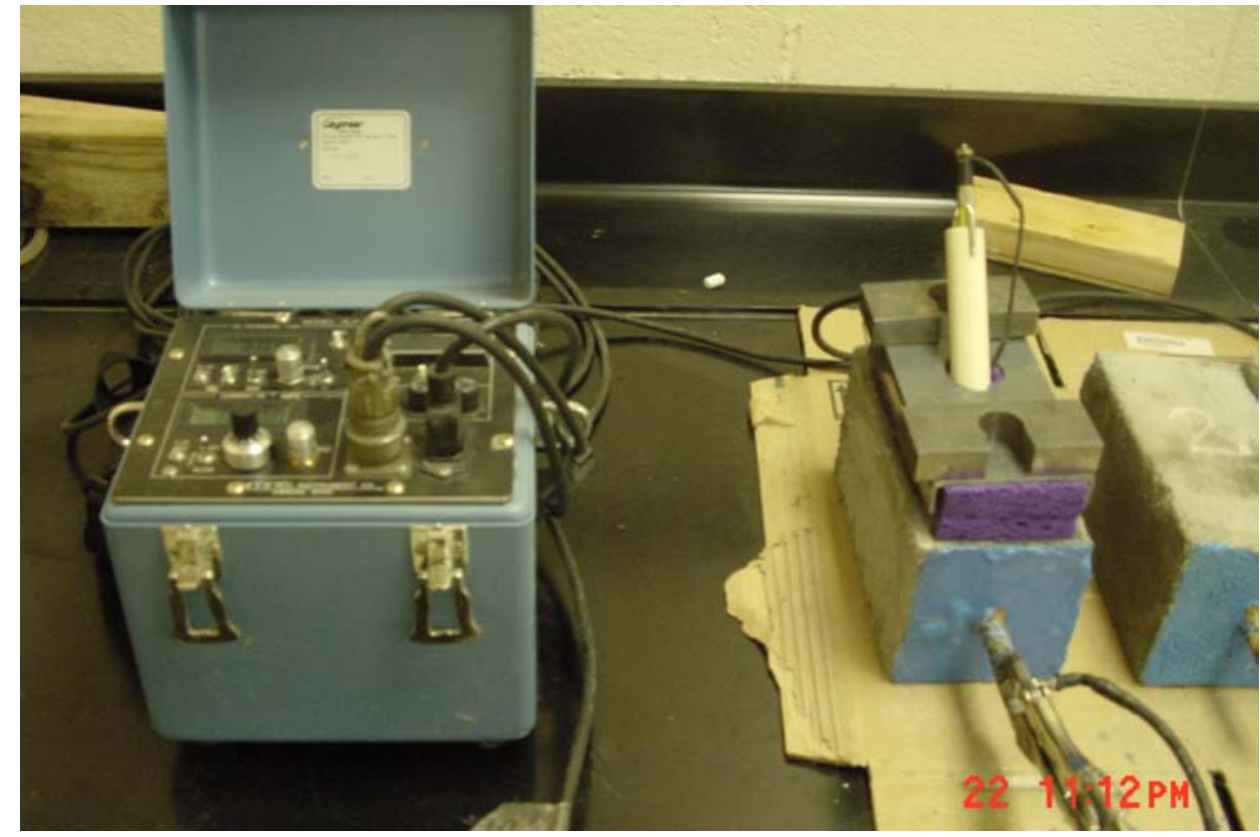

Figure 9: Experimental setup for 3-LP device

The 3-LP device usually underestimates the corrosion rate. The predicted corrosion rate would be 0.93 of actual corrosion rate ${ }^{14}$. 
The following steps were involved in using 3-LP device for corrosion rate measurements:

- The control knobs on the device should be in the following positions before starting the test. Offset knob should be turned counter clockwise till the end. The switch should be in the middle position.

- Keep the voltage range on the $2000 \mathrm{mV}$ range.

- The fast-off-slow switch should be off.

- Make sure the current knob should read zero at the beginning of every test.

- The current switch that is labeled as 2-20-200 mA should be on $2 \mathrm{~mA}$.

- Make the sponge wet using 5\% detergent solution. Place it on the concrete block with larger side parallel to the steel rebar. Make sure that no solution seeps outside the sponge area on the concrete. Place weights of approximately one kilogram above the sponge area to provide uniform contact with the concrete surface.

- Insert the copper sulfate reference electrode into the PVC (Poly Vinyl Chloride) tube so that the reference cell has contact with the sponge. Connect the reference cell to the black wire.

- Connect the wire coming from the probe cable to the rebar by means of vise grips.

- After the connections are verified, power switch is turned ON. Make sure that the digital ammeter should read zero and the digital voltmeter will read the static potential at the test location. Reset the timer to zero.

- Turn the Fast-off-slow switch to fast and wait till the potential stabilizes for at least three minutes.

- Turn the offset switch to + and turn the knob until the voltmeter reads zero. 
- Make sure that both the digital ammeter and voltmeter read zero or adjust the zeroadjustment screws to read zero.

- Slowly turn the current adjust knob until the digital voltmeter reads a value (probably $2 \mathrm{mV})$.

- Repeat this procedure approximately every $2 \mathrm{mV}$ until it reaches $12 \mathrm{mV}$.

- After that, turn the current adjust knob to zero and reset the timer to zero. Record the potential and time in sec.

- Turn off the null switch and record the end potential. Test is completed.

The 3-LP device has the following limitations. It cannot be used when the rebar is coated or when the rebar is more than 4 inch depth from the concrete surface due to high ohmic resistance.

\subsection{Chloride Analysis Method}

In this study, the chloride ion concentrations in the concrete samples were determined using a technique described in ASTM D2361-85. This method is based on a back titration in which an excessive amount of silver nitrate is added to precipitate chloride ion as silver chloride and the excess is treated with potassium thiocyanate solution using an indicator of ferric ammonium sulfate.

1. A hole of $0.0125 \mathrm{~m}$ was drilled in the center of one of the four sides of the spent concrete block. The powder produced by drilling was mixed and 3 grams of the sample was mixed with $50 \mathrm{ml}$ of distilled water was added and boiled for 30 minutes.

2. The boiled solution was filtered using a Whatman No.1 filter paper. The solid was washed at least 5 times, using $10 \mathrm{ml}$ of hot water at the end of each wash (the concrete 
sample was boiled and washed with hot water because chloride ion might exist as physically adsorbed ion on the concrete, and the adsorption of this ion will decrease as temperature increases).

3. The filtrate was cooled and acidified by adding $20 \mathrm{ml}$ of nitric acid (the solution was concentrated in order to prevent the formation of the hydrate, AgOH). Twenty milliliters of an $\mathrm{AgNO}_{3}$ stock solution (0.025 molar) was added to the filtrate. In time, $\mathrm{AgCl}$ was precipitated. The whole content was boiled for 30 minutes (the $\mathrm{AgCl}$ was precipitated because it is very much insoluble in water with the solubility of $1.34 \times 10^{-5}$ molar).

4. The precipitate was filtered using a Whatmon No. 42 filter paper, and the solid was washed 5 times, each time using $10 \mathrm{ml}$ of hot distilled water.

5. Five milliliters of ferric ammonium sulfate was added to the filtrate. It was used as an indicator.

6. Then it was titrated with potassium thiocyanate solution (0.0305 molar). The end point was reached when the solution becomes reddish brown in color.

\subsection{Corrosion Study of Bare Steel Rebars}

In the second study, three pieces each of HC and CV steel $(0.0125 \mathrm{~m}$ OD x $0.05 \mathrm{~m}$ long) were placed in sodium chloride solution into which air was bubbled. Air was bubbled to accelerate the corrosion. The pieces were taken out in regular time intervals of 16,23 and 30 days and the corrosion products were scrapped from the substrate by a blade. Then, the steel pieces were dried using infrared light and weighed. The weight loss was determined as a function of time, which was used to determine the corrosion rate of rebar. The steel pieces were returned to the bucket for continuation of the test. The concentrations of sodium chloride used for this study were $0.1,0.5,1.7$ and 3.0\%. The HC steel's rust was reddish 
brown whereas the conventional one was black in color. Figure 10 shows the color distinction of these two products. The corrosion products removed were rinsed by hot distilled water to remove the loosely held chloride. Then the corrosion products were dried using infrared light.

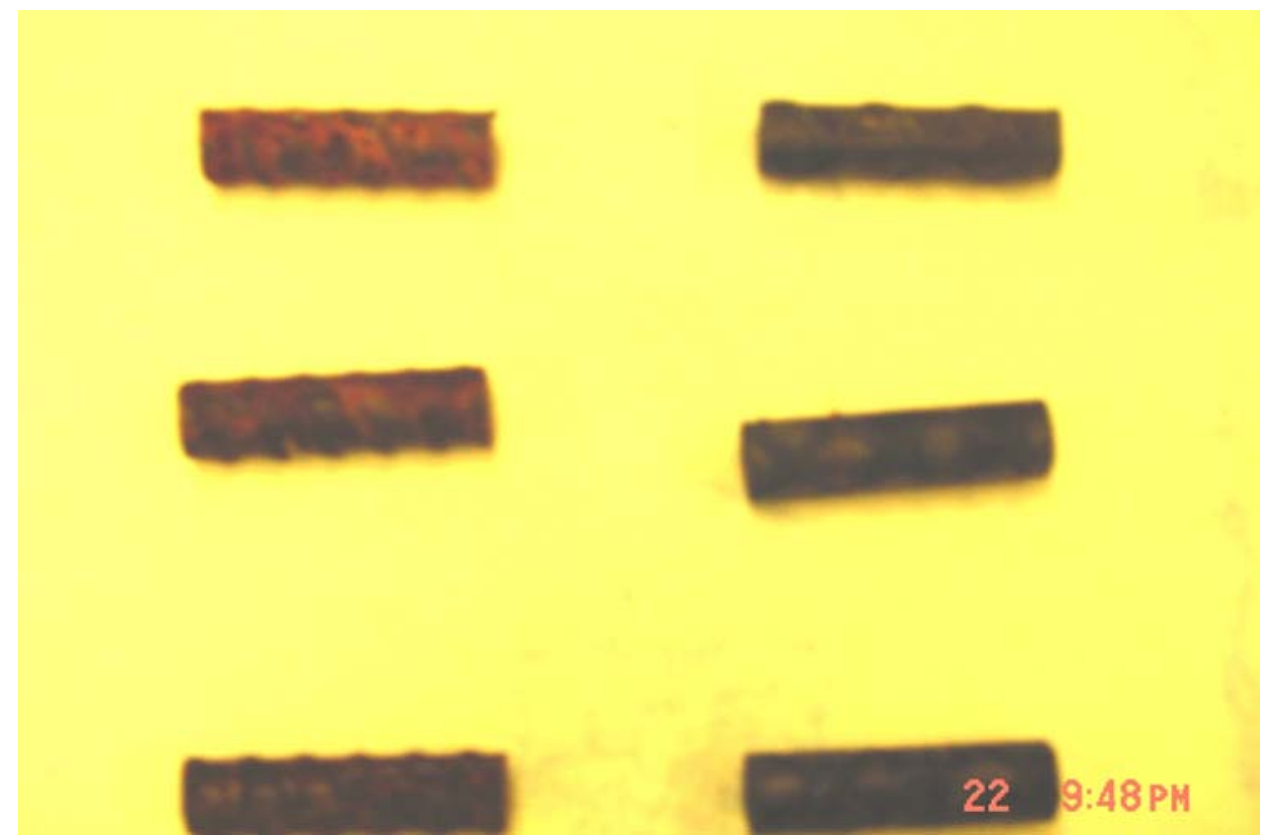

Figure 10: Corrosion products on the surface of the steel showing reddish brown product in HC steels (left) and black products in the CV steel (right)

\subsection{Chemical Analysis Method}

The corrosion products removed from the surface of the rebar were analyzed to determine its composition. Only those corrosion products collected from tests conducted with 1.7 and 3\% sodium chloride solution were used for this analysis. Initially, the corrosion products were dissolved by boiling nitric acid ( 1 part +7 parts water). Then to dissolve the remaining insoluble products aqua-regia solution $(50 \mathrm{ml})$ was used and boiled for 
approximately one hour. A small amount of the product (up to $0.083 \mathrm{~g}$ ) was dissolved. After one hour the leach content was filtered. The insoluble content of the leach product retained in the filter was burned in an oven at $600{ }^{\circ} \mathrm{C}$ for 2 hours to determine the weight. The filtrate was diluted and analyzed with an atomic absorption spectrophotometer for $\mathrm{Fe}, \mathrm{Cr}, \mathrm{Mn}, \mathrm{Cu}$ and $\mathrm{Ni}$.

\subsection{Particle Size Distribution Analysis}

In this study, particle size distribution of corrosion products of $\mathrm{HC}$ and $\mathrm{CV}$ steels was analyzed. Prior to the experiment, the average particle density of both steel corrosion products were calculated using density of the specific oxide compound and the chemical analysis results. The percentage of oxide compound in the sample was estimated by the chemical analysis data. The average densities of HC and CV samples were found to be 4.754 $\mathrm{g} / \mathrm{cm}^{3}$ and $4.689 \mathrm{~g} / \mathrm{cm}^{3}$, respectively.

This particle size analysis was based on the settling velocity of the solid particle in the fluid. Stokes equation was used to calculate the settling velocity of fine spherical particles under laminar flow regime ${ }^{15}$. An expression of Stokes equation is:

$V=\frac{d^{2}\left(\rho_{s}-\rho_{l}\right) g}{18 \mu}$

where $\mathrm{V}=$ particle settling velocity

$\mathrm{d}=$ particle diameter

$\rho_{\mathrm{s}}=$ particle density

$\rho_{1}=$ fluid density

$\mu=$ fluid viscosity

$\mathrm{g}=$ acceleration of gravity 
Since the settling velocity of the particle is proportional to the square of its diameter, finer material stays in suspension longer than coarse material, and can be decanted from a settling suspension several times in succession, and an effective size separation can be made.

In the experiment about 0.275 grams of the corrosion product sample was placed in a $100 \mathrm{ml}$ graduated cylinder. Distilled water was added to $100 \mathrm{ml}$ mark of the cylinder. Potassium phosphate of 0.01 grams was added to the slurry as a dispersing agent. Settling velocities of corrosion products of various sizes such as 5, 9, 13, 26 and 37 microns were calculated. Then, the time required for these particles to reach $10 \mathrm{~cm}$ was calculated.

The cylinder was shaken to make the solid concentration homogeneous and then left for a period until 5 microns particles settled $10 \mathrm{~cm}$ below the surface of the slurry. Three milliliters of the slurry was withdrawn at the $10 \mathrm{~cm}$ level below the surface and placed in a beaker. The slurry was air dried and the weight of the solid was determined. The fraction of particles that was finer than 5 micron particle was calculated by dividing the solid weight by the one contained in $3 \mathrm{ml}$ of the homogeneous solid concentration. These procedures were repeated for other particle sizes. A Gaudin - Schuhmann plot was made for the weight fraction of particles finer than $\mathrm{d} v$ s diameter of the particle.

$Y(d)=\left(\frac{d}{d_{\max }}\right)^{\alpha}$

where $Y(d)=$ fraction of particles finer than $d$

$$
\begin{aligned}
& d=\text { particle size } \\
& d_{\max }=\text { maximum size of the particle } \\
& \alpha=a \text { constant }
\end{aligned}
$$


Once $\alpha$ and $\mathrm{d}$ were determined, the average particle size was determined by

$$
d_{\text {avg }}=\left(\frac{\alpha}{\alpha+1}\right) d_{\max }
$$

\subsection{X-ray Diffraction Analysis}

When a beam is incident on a crystalline material, the scattered beams may add together in a few directions and reinforce each other to give diffracted beams. The regularity of arrangement of atoms in the crystal was responsible for the diffracted beams otherwise the scattered beam would randomly add together or cancel each other. The formation of diffracted beams depends on the wavelength, $\lambda$; spacing of planes of atoms $d$ and the angle of incidence of beam, $\theta$. The equation shown below is known as Bragg's law.

$\mathrm{n} \lambda=2 \mathrm{~d} \sin \theta$

The wavelength of X-rays used in X-ray diffractometers is around 0.1 to $0.2 \mathrm{~nm}$, which is similar to the spacing of atoms in the structure of most minerals. The similarity in dimensions means that the regularly spaced atoms that comprise a crystal diffract X-rays. It can be inferred that the layers of atoms produce diffraction effectively, reflects the incident $\mathrm{X}$-rays (angle of incidence $\theta$ is appropriate). Diffraction occurs whenever Bragg's law is satisfied. If a monochromatic x-ray beam is directed at a single crystal, then only one or two diffracted beams will result. A powder sample having hundreds of crystals diffracts the xrays in accordance with Bragg's law produce continuous cones of diffracted beams ${ }^{16}$.

X-ray Diffraction was used for identifying the corrosion product of the steel. Every crystal produces a unique diffraction pattern from which its presence can be identified ${ }^{17}$. Rigaku/USA x-ray diffractometer was used for the analysis. About 0.75 grams of the corrosion product of both steels were used. The samples were analyzed for angles between 
10 to $90^{\circ}$. A crystalline material was identified from its diffraction pattern by comparing diffraction angles and its peaks shown in the pattern and those shown in the standard diffraction pattern. 


\section{Chapter 4}

\section{Results and Discussion}

In the first study, corrosion rate of high-chromium and conventional steels reinforced in concrete were compared using 3-LP device, and the chloride ions present in the concrete blocks were also determined. In the second study, corrosion rates of bare steel rebars of high-chromium and conventional steels were determined and compared. Corroded products were analyzed using chemical analysis method to determine the composition of the product layer, followed by particle size distribution to determine the characteristic formation of adherent product layer in these steels. Finally, X-ray diffraction was used to cross verify the chemical analysis method and also to identify the minerals present.

\subsection{Corrosion Study of Concrete Blocks}

In this study, twelve concrete blocks were cast using six rebars of high-chromium steel and six rebars of conventional steel. The samples numbered 1 to 6 were immersed in $1.7 \%$ sodium chloride concentration with two concrete blocks in each container in the same order. Similarly, samples numbered 7 to 12 were immersed in $3 \%$ sodium chloride concentration with two concrete blocks in each container in the same order. These blocks were withdrawn periodically and the corrosion rate was measured using 3-LP device.

The data obtained from the study with concrete blocks were plotted for change of potential with respect to change of current. The plot shown in Figure 11 was for HC steel after 132 days of exposure in $3 \%$ sodium chloride solution. Similar plot shown in Figure 12 was drawn for $\mathrm{CV}$ steel after 132 days of exposure in $3 \%$ sodium chloride concentrations. 


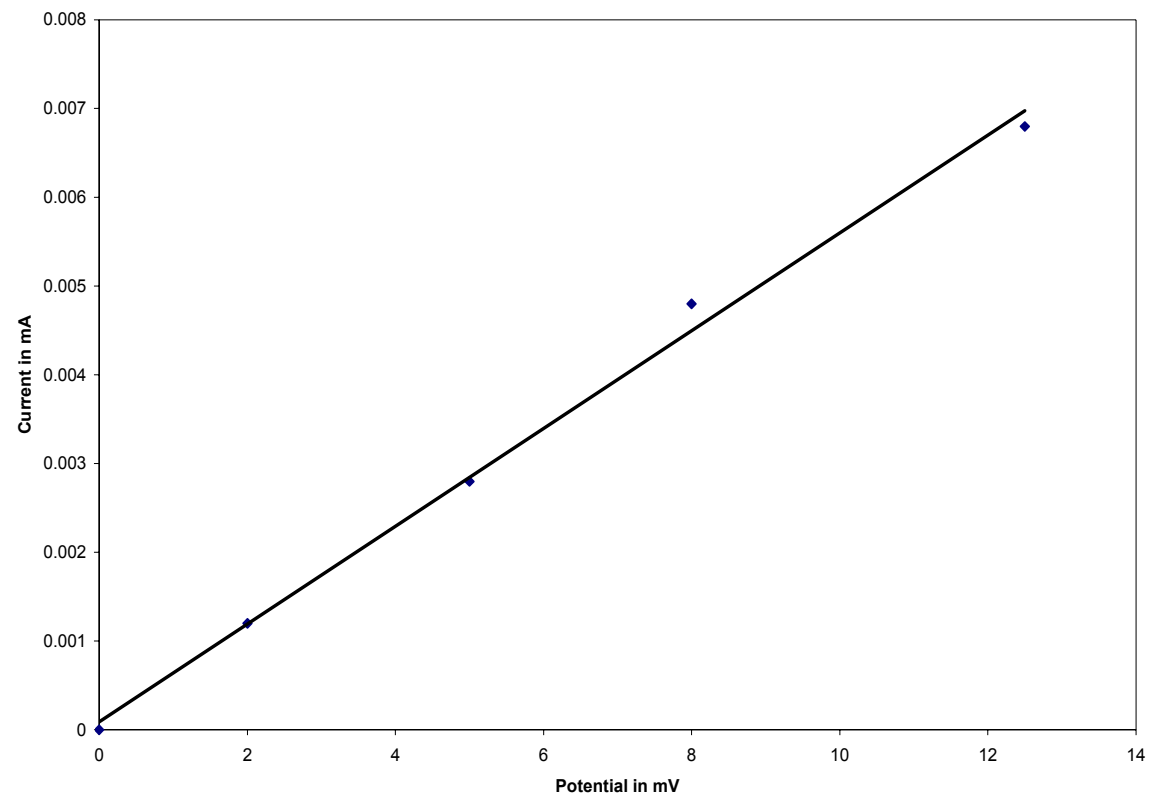

Figure 11: Variation of potential with respect to current for specimen - 8 (HC steel) after 132 days of immersion in $3 \%$ of sodium chloride

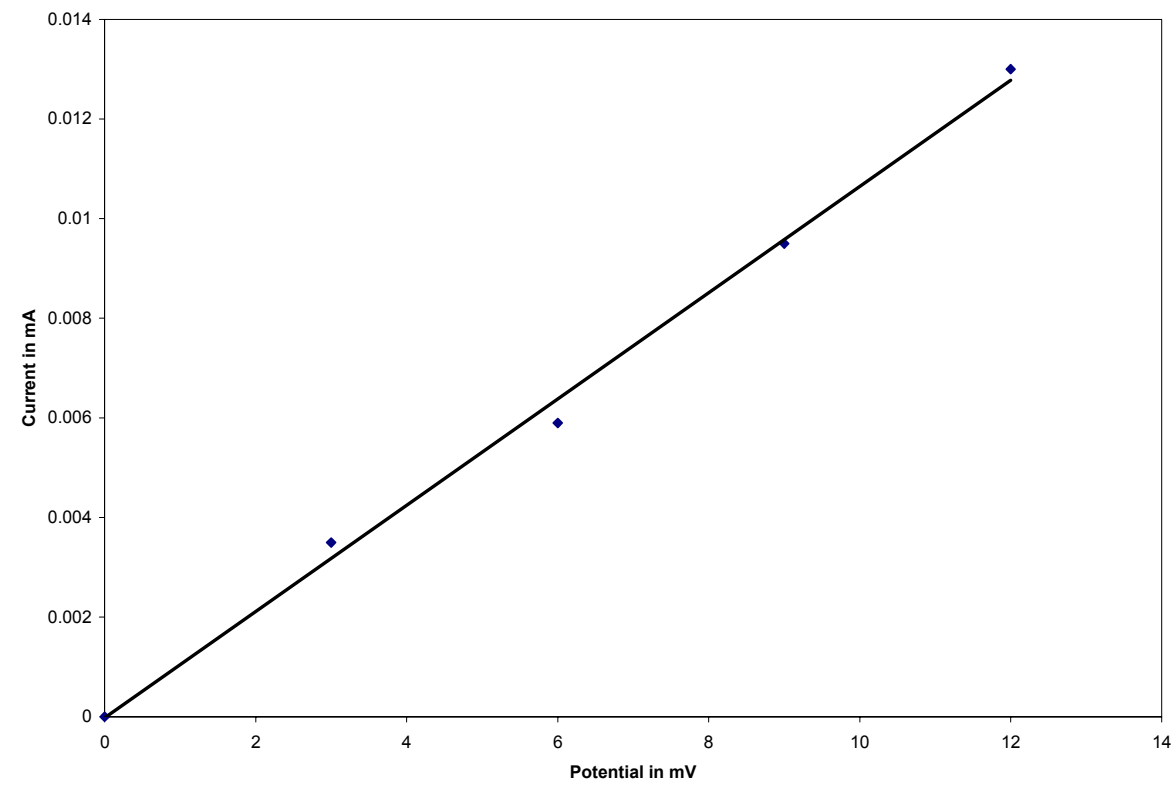

Figure 12: Variation of potential with respect to current for specimen - 12 (CV steel) after 132 days of immersion in $3 \%$ of sodium chloride 


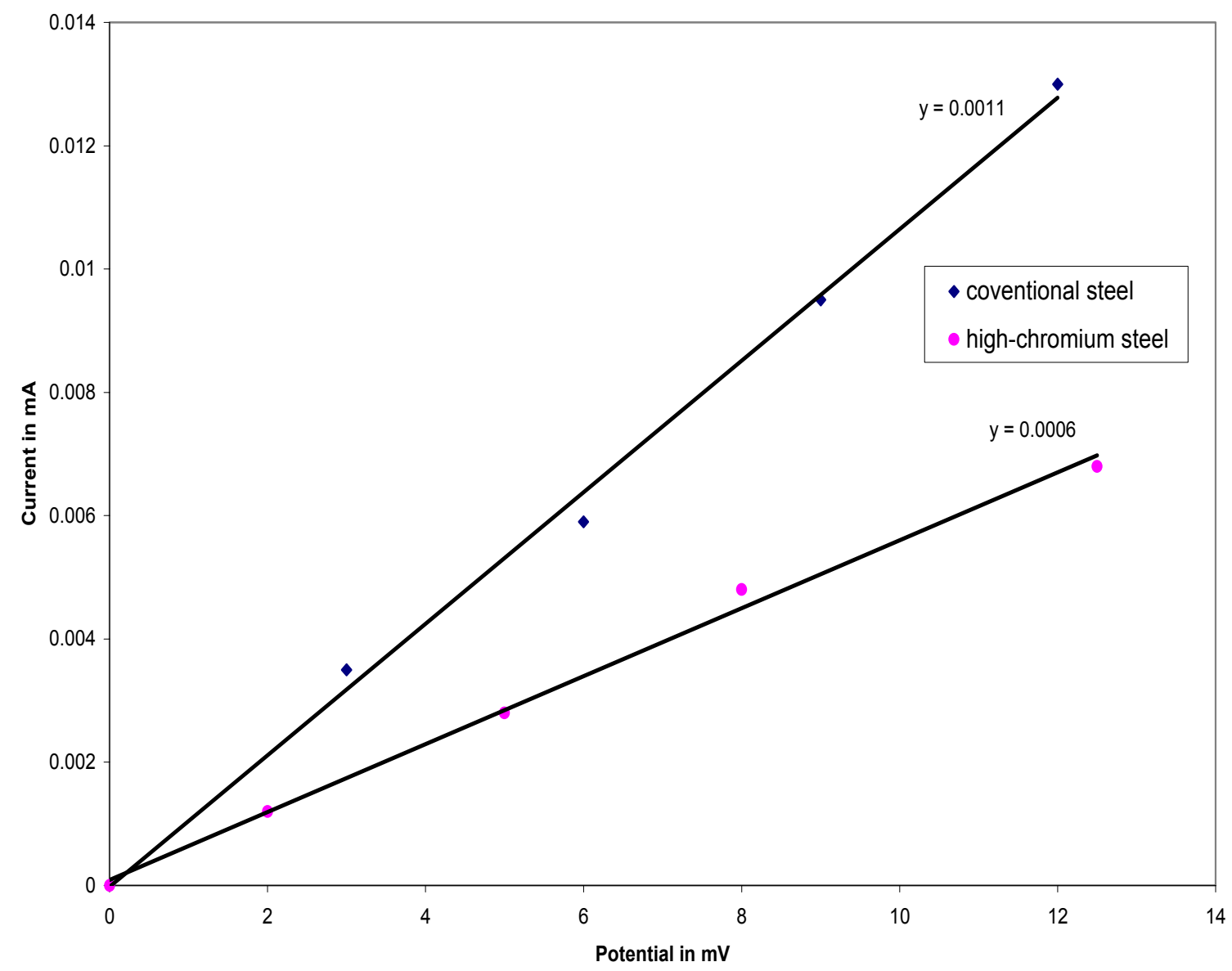

Figure 13: Comparison of variation of potential with respect to current for specimens 8 and 12

Figure 13 compares the variation of potential with respect to current for concrete blocks reinforced with high-chromium and conventional steel at the end of 132 day period. It can be observed that the data from the figures fit into straight lines. Polarization resistance is obtained from slope of these straight lines. The value of the slope is found to be higher in conventional steel than high-chromium steel. Corrosion rates were determined using SternGeary Equation (13) and the results are shown in Figure 14.

$I_{\text {corr }}=\frac{\Delta I_{a p p}\left(\beta_{a} \times \beta_{c}\right)}{2.3 \Delta \varphi\left(\beta_{a}+\beta_{c}\right)}$ 


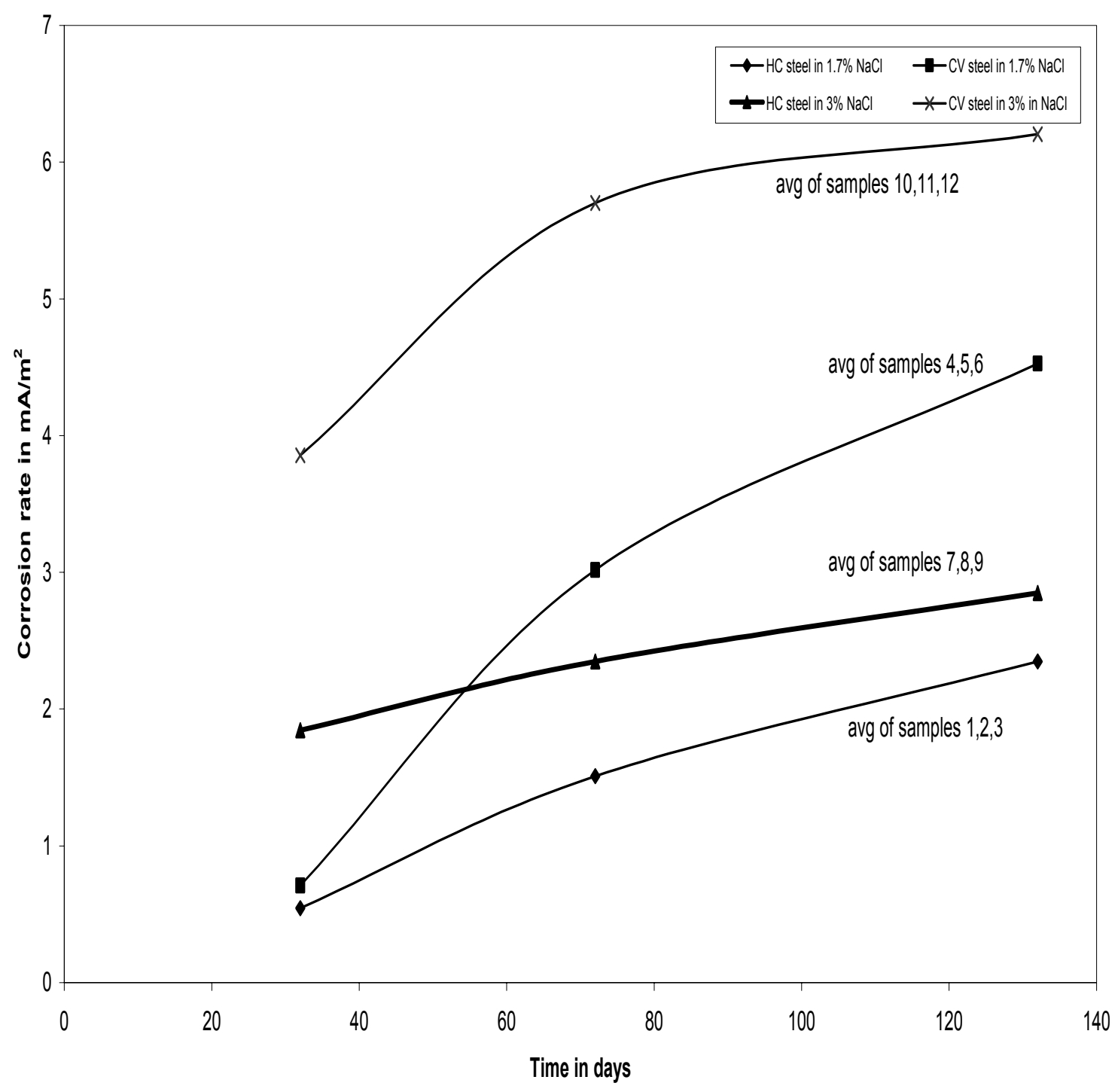

Figure 14: Average corrosion rate of steel in concrete with respect to time

The corrosion rates plotted in the Figure 14 were the average values obtained from three concrete blocks exposed to same concentration. For example, HC steel in $1.7 \%$ sodium chloride concentration represents average values of samples 1,2 and 3. It can be seen from Figure 14 that the corrosion rates of conventional steel rebar are higher than those of high-chromium steel rebar. Figure 12 shows that the corrosion rates of conventional rebars were approximately twice as high as high-chromium rebar after 132 days of exposure. 


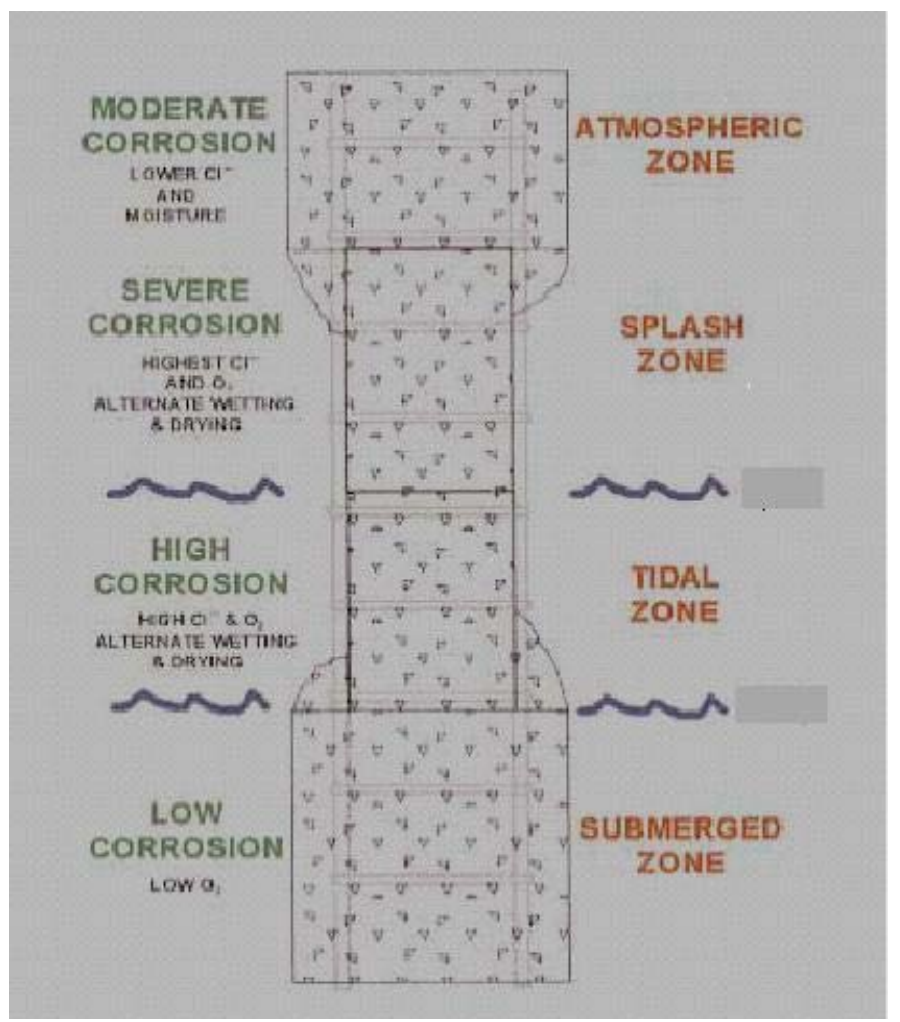

Figure 15: Corrosion regions of a concrete pile in a marine environment ${ }^{18}$

The presence of chloride ions at dry, tidal and submerged zones were found to be in the range of $1.1 \%$ of chloride by cement, $8 \%$ chloride by cement and $2.6 \%$ chloride by cement ${ }^{19}$. Figure 15 shows the corrosion regions of a concrete pile in a marine environment. Each zone is found to have different corrosion rates. In submerged zone, oxygen has to diffuse through the water and it is limited, hence lower corrosion rate. In the atmosphere, lower corrosion rate due to the limited chloride and moisture. Corrosion is found to be severe in splash and tidal zones. Higher moisture content leads to higher conductivity of concrete and moreover coupling of these zones with other regions of the structures result in macro-cell corrosion. Relative humidity was also found to play a major in corrosion. When the relative humidity is less than $60 \%$ and greater than $95 \%$, there is no risk of corrosion. 
Since concrete has little pore solution when the relative humidity is less and when more pore solution is present in the concrete, oxygen has to diffuse through the solution ${ }^{20}$. Thus, corrosion rate is found to be high, when the relative humidity varies from 70 to $90 \%$.

\subsection{Chloride Analysis Method}

The chloride analysis was made on the samples taken from the concrete blocks after 132 days of accelerated testing. The results are tabulated in Table 8 . From the results it is evident that the amount of chloride ions present in the concrete blocks immersed in $3 \%$ sodium chloride solution was found to be higher than that in the concrete blocks immersed in $1.7 \%$ sodium chloride solutions. The chloride concentrations of the concrete block were found to be well above the threshold limit of $0.6713 \mathrm{~kg} / \mathrm{m}^{3}(0.05 \mathrm{wt} \% \text { of concrete })^{4}$.

From Figure 14, the ratio of the corrosion rate between $\mathrm{CV}$ and $\mathrm{HC}$ is about 2. However, this ratio is not the same as the ratio of chloride present in the concrete blocks of $\mathrm{CV}$ and HC steel rebars. This is understandable because the chloride ions do not take part in corrosion reactions directly, but they depassivate the product layer and can lead to corrosion under certain environmental conditions. 
Table 8 Average concentration of chloride ions in concrete blocks in PPM

\begin{tabular}{|l|l|l|l|}
\hline $\begin{array}{l}\text { Sample } \\
\text { number }\end{array}$ & $\begin{array}{l}\text { Concrete blocks in } \\
\mathbf{1 . 7 \%} \text { sodium } \\
\text { chloride solution }\end{array}$ & $\begin{array}{l}\text { Sample } \\
\text { number }\end{array}$ & $\begin{array}{l}\text { Concrete blocks in } \\
\text { 3\% sodium chloride } \\
\text { solution }\end{array}$ \\
\hline 1 & 959 & 7 & 1693 \\
2 & 828 & 8 & 1080 \\
3 & 611 & 9 & 1766 \\
\hline 4 & 683 & 10 & 1261 \\
5 & 792 & 11 & 1225 \\
6 & 899 & 12 & 1405 \\
\hline
\end{tabular}

\subsection{Corrosion Study of Bare Steel Rebars}

In this study, corrosion rate is determined by weight loss of rebars. The corroded products are then analyzed using chemical analysis method, particle size distribution analysis and X-ray diffraction to study their characteristics and to identify the minerals present in them.

The weight losses of the bare rebars of the conventional steel and high-chromium steel are plotted as a function of time at four different sodium chloride concentrations. The data plotted in Figure 16 is the average value of three samples exposed to same concentrations. For example, $\mathrm{HC}$ steel in $0.1 \%$ sodium chloride concentration is represented by samples a, b and c. From the plots, we can see that the corrosion rate of conventional steel is much higher than that of high-chromium steel. The slope of each straight line represents the corrosion rate and shown in Table 9. The corrosion rate in Table 9 is given as percentage of weight loss per day. We can compare the corrosion rate of $\mathrm{CV}$ with that of $\mathrm{HC}$ steel at $0.1 \%$ sodium chloride. The rate of conventional steel is about 12 times of $\mathrm{HC}$ steel. 
However, as the concentration of sodium chloride increases, the rate ratio decreases. It can be seen from Table 9 that the ratio decreases to 2 times when the sodium chloride concentration increases to $3 \%$. The reason for this behavior cannot be concluded from this work. Figure 13 and Table 9 show a distinctive behavior between the two steel rebars.

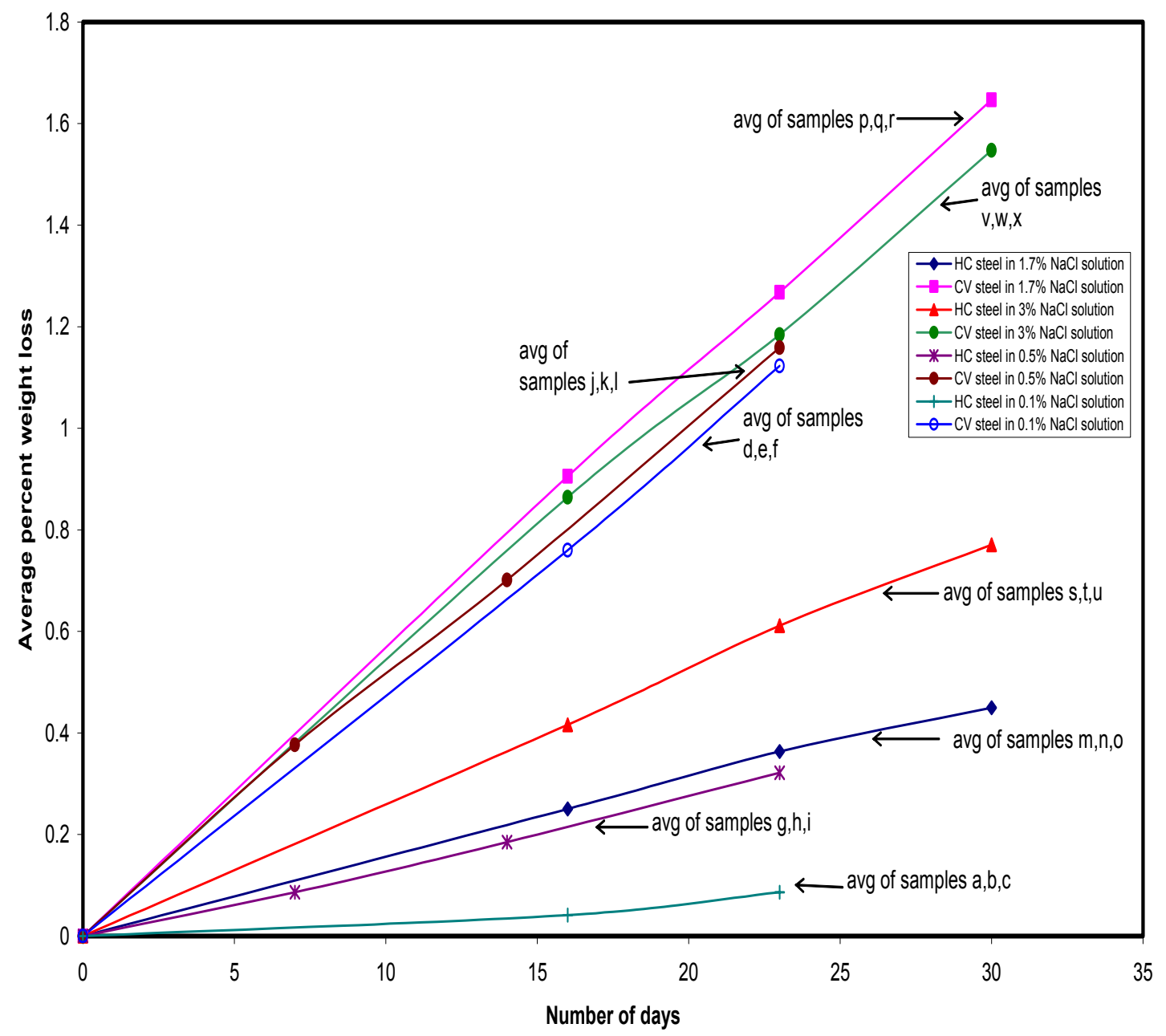

Figure 16: Average percent weight loss of $\mathrm{HC}$ and $\mathrm{CV}$ steel in sodium chloride solutions

The corrosion rate of conventional steel is not sensitive to sodium chloride

concentration while the opposite is true for the high-chromium steel. In Figure 16, the switch 
over between 1.7 and 3\% sodium chloride for conventional steel is abnormal and considered to be an experimental error. One can see from Table 9 that the difference in corrosion rate between 0.1 and $3 \%$ of sodium chloride for conventional steel was only $6 \%$ while that with the high-chromium steel was about $700 \%$. However, one should note that this corrosion rate of $\mathrm{HC}$ is still much lower than that of $\mathrm{CV}$.

Table 9 Percent weight loss/corrosion rate of $\mathrm{HC}$ and $\mathrm{CV}$ steel rebars

\begin{tabular}{|l|l|l|}
\hline Steel rebar & $\begin{array}{l}\text { Sodium chloride } \\
\text { concentration (\%) }\end{array}$ & $\begin{array}{l}\text { Percent weight loss } \\
\text { per day (Corrosion } \\
\text { rate) }\end{array}$ \\
\hline \multirow{4}{*}{$\mathrm{HC}$} & $\begin{array}{l}\text { 0.1 (a, b, c) } \\
\text { 0.5 (g, h, i) }\end{array}$ & 0.0036 \\
& $1.7(\mathrm{~m}, \mathrm{n}, \mathrm{o})$ & 0.014 \\
& $3.0(\mathrm{~s}, \mathrm{t}, \mathrm{u})$ & 0.0152 \\
\hline \multirow{3}{*}{$\mathrm{CV}$} & $0.1(\mathrm{~d}, \mathrm{e}, \mathrm{f})$ & 0.0259 \\
& $0.5(\mathrm{j}, \mathrm{k}, \mathrm{l})$ & 0.0486 \\
& $1.7(\mathrm{p}, \mathrm{q}, \mathrm{r})$ & 0.05 \\
& $3.0(\mathrm{v}, \mathrm{w}, \mathrm{x})$ & 0.0515 \\
\hline
\end{tabular}

\subsection{Chemical Analysis Method}

The distinctive difference in corrosion behavior between the two steel rebars as shown in Figure 16 was explained by the chemical analysis results of the corrosion products. The analysis results are provided in Table 10. The basic difference is due to weight percent of Fe and Cr. The corrosion product of $\mathrm{CV}$ has higher iron content. The corroded metal on $\mathrm{CV}$ steel was black while that of $\mathrm{HC}$ steel was reddish brown. Magnetite, $\mathrm{Fe}_{3} \mathrm{O}_{4}$ is usually black and theoretical iron content is $72.4 \%$ while hematite, $\mathrm{Fe}_{2} \mathrm{O}_{3}$ is usually reddish brown 
and its theoretical iron content is $69.9 \%$. From the iron content data and the observed colors we conclude that the corrosion product on CV steel is predominantly magnetite and that on $\mathrm{HC}$ steel is predominantly hematite.

Table 10 Chemical analysis results for corrosion products (wt \%)

\begin{tabular}{|l|l|l|l|l|}
\hline \multirow{2}{*}{ Metals } & \multicolumn{2}{|l|}{$\begin{array}{l}\text { 3\% Sodium chloride } \\
\text { solution }\end{array}$} & \multicolumn{2}{l|}{$\begin{array}{l}\text { 1.7\% Sodium } \\
\text { chloride solution }\end{array}$} \\
\cline { 2 - 5 } & HC & CV & HC & CV \\
\hline $\mathrm{Fe}$ & 50.43 & 56.23 & 55.22 & 61.73 \\
\hline $\mathrm{Cr}$ & 5.81 & 0.77 & 5.54 & 0.70 \\
\hline $\mathrm{Mn}$ & 0.25 & 0.89 & 0.15 & 0.78 \\
\hline $\mathrm{Ni}$ & - & 0.32 & - & 0.56 \\
\hline $\mathrm{Cu}$ & - & 0.25 & - & 0.18 \\
\hline
\end{tabular}

The discreet values of chromium content between the two steels as given in Table 10 may give a clue to the formation of these product layers on these steels. The chromium content in the product of $\mathrm{HC}$ steel may catalyze the oxidation of steel to hematite whose oxidation number is higher than that of magnetite. This surmise may be justified by the experience when we removed the corrosion products from the substrate of the steel rebars. The corrosion product on CV steel was easily removed; however, the corrosion product on HC steel was resilient and cannot be easily removed. It was observed that magnetite adheres less to the surface of the steel and thus making the product layer to be more porous while hematite in $\mathrm{HC}$ steel adheres to the surface more intimately and thus making the product layer of $\mathrm{HC}$ to be less porous. 


\subsection{Particle Size Distribution Analysis}

Smaller particles would tend to provide larger diffusion resistance and the opposite holds for larger particle size. Hence particle size analysis was conducted to determine the average particle sizes of two steels. The particle size distribution data are plotted in Figure 17. From the plots for both corrosion products, $\mathrm{d}_{\max }$ and $\alpha$ were determined, which also determines the average size. The average size was found to be $16.8 \mu \mathrm{m}$ and $9.54 \mu \mathrm{m}$ for high-chromium and conventional steel corrosion products, respectively. Since the particle size of the corrosion product of conventional steel is smaller than that of the high-chromium steel, the discreet corrosion rates of the two steel rebars cannot be explained in terms of particle size.

\subsection{X-ray Diffraction Analysis}

The distinct corrosion behavior of the two steel rebars as shown in Figure 16 was explained using the X-ray diffraction results. Figures 18 and 19 portray the $\mathrm{X}$-ray diffraction patterns of corrosion products of CV and $\mathrm{HC}$ steel, respectively. Strong peaks of magnetite $\left(\mathrm{Fe}_{3} \mathrm{O}_{4}\right)$ and weak peaks of lepidocrocite $(\mathrm{FeOOH})$ are shown in Figure 18 for the conventional steel corrosion products. Similarly, from Figure 16 only peaks of lepidocrocite $(\mathrm{FeOOH})$ and hematite $\left(\mathrm{Fe}_{2} \mathrm{O}_{3}\right)$ are seen for the high-chromium steel corrosion product. These x-ray diffraction results would agree with the chemical analysis results. 




Figure 17: Particle size distribution for corrosion products 


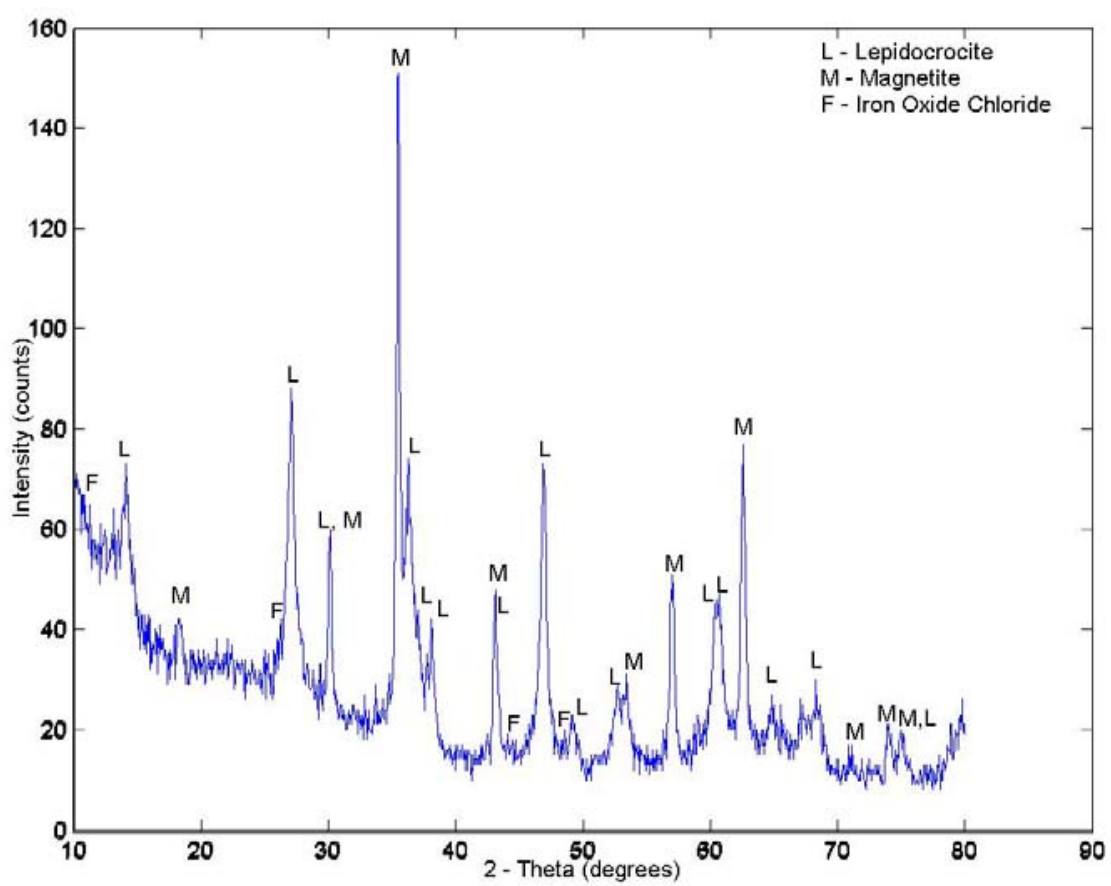

Figure 18: $\mathrm{X}$-ray diffraction analyses on corrosion products of $\mathrm{CV}$ steel

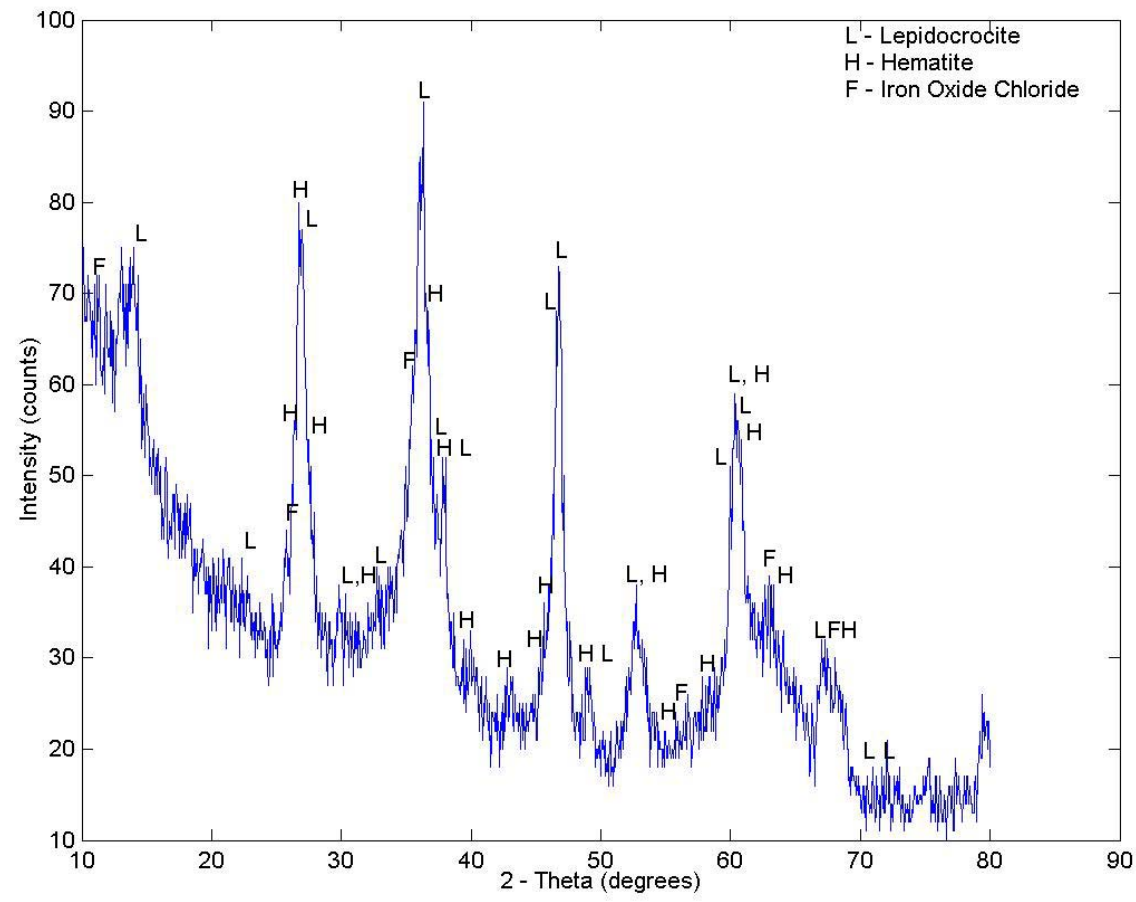

Figure 19: X-ray diffraction analyses of corrosion products on HC steel 


\section{Chapter 5}

\section{Conclusions}

High-chromium and conventional steels are compared for their corrosion rates by reinforcing in concrete blocks under varying parameters, i.e., concentration levels of sodium chloride, constant $\mathrm{pH}$ and room temperature for a period of 32,72 and 132 days. Bare steel rebars are also exposed to similar conditions for a period of 16, 23 and 30 days. In both studies high-chromium steel is found to perform better than conventional steel under chloride environment. The conclusions drawn from the experimental results are listed below.

- It is found that corrosion of steel rebar in concrete blocks increases as the concentration of sodium chloride increases.

- The corrosion rate of conventional steel rebar is twice as much as that of the highchromium steel rebar when the concrete blocks were exposed for 132 days.

- In the corrosion of bare steel rebar pieces it is found that the corrosion rate of conventional steel remains almost at the same level in all concentrations of sodium chloride whereas that of high-chromium steel increases as the sodium chloride concentration increases.

- The ratio of corrosion rates of conventional steel to high-chromium steel decreases from 12 to 2 times as the concentration of the sodium chloride increases from 0.1 to $3.0 \%$. It is found that the corrosion rate of high-chromium steel was very sensitive to sodium chloride concentration; i.e., the rate increased as the concentration increased. 
- It has been found from the X-ray diffraction that the corrosion of high-chromium steel produces lepidocrocite and hematite while the corrosion of conventional steel produces magnetite.

- Lepidocrocite and hematite would provide a resilient and adherent passive film on high-chromium steel rebars while magnetite would provide a less resilient and adherent film on conventional steel. These different films produce discrete corrosion rates as observed from both studies with concrete blocks and bare steel rebars.

- Thus, high-chromium steel rebar performs outstandingly well against chloride induced corrosion in comparison to conventional steel rebars. 


\section{Chapter 6}

\section{References}

1. WwW.corrosioncost.com

2. Carl E. Locke, "Corrosion of Steel in Portland Cement Concrete: Fundamental Studies", Corrosion Effect of Stray Currents and the Techniques for Evaluating Corrosion of Rebars in Concrete, ASTM STP 906, American Society for Testing and Materials, pages 5-14, 1986.

3. H. Uhlig, "Corrosion and Corrosion Control", Second Edition, Wiley Publications, 1971.

4. John P. Broomfield, "Corrosion of Steel in Concrete - Understanding, Repair and Investigation, First Edition, E \& FN Sons, 1997.

5. Fontana and Greene, “Corrosion Engineering”, McGrawHill Publications, 1979.

6. R.A. Antunes, I. Costa, D.LA. de Faria, "Characterization of Corrosion Products Formed on Steels in the First Months of Atmospheric Exposure, Materia, Volume 8. pages 27-34, 2003.

7. Desmond C. Cook and Ann C. Van Orden, "The Lulling Bridge: An Inside Story", Corrosion, 2000.

8. www.alpsi.com

9. Denny A. Jones, "Principles and Prevention of Corrosion", Second Edition, Prentice H Hall Publications, 1995.

10. Eung Ha Cho and Ram Chamarthy, "Corrosion Condition Evaluation at Muddy Creek Bridge”, Journal of Performance of Constructed Facilities, ASCE, 2003. 
11. J. R. Scully, "The Polarization Resistance Method for Determination of Instantaneous Corrosion Rates: A Review”, Corrosion, Vol. 56, pages 227-242, 2000.

12. www.mmfxsteel.com

13. D. Whiting, "Concrete Materials, Mix Design, Construction Practices, and their Effects on the Corrosion of Reinforcing Steel”, Corrosion/78, Paper No. 73, Houston, Texas, 1978.

14. Kenneth C. Clear, "Measuring Rate of Corrosion of Steel in Field Concrete Structures", KCC Inc, 3-LP Operational Manual, 1989.

15. Riyadh R. Irani and Clayton F. Callis, "Particle Size: Measurement, Interpretation and Application", John Wiley and Sons, Inc., NY, 1963.

16. www.matter.org.uk

17. David Brandon and Wayne D. Kaplan, "Microstructural Characterization of Materials", John Wiley and Sons, NY, 1999.

18. www.porttechnology.org

19. Andrew Griffith and Martin Laylor, "Epoxy Coated Reinforcement Study", Final Report, State Research Project \#527, Oregon Department of Transportation, June 1999.

20. www.alpha.co.za

21. W. Hime and B. Erlin, "Some Chemical and Physical Aspects of Phenomena Associated with Chloride Induced Corrosion", American Concrete Institute, SP-102, pages 1-12, 1987.

22. John Fraczek, "Corrosion, Concrete and Chlorides", American Concrete Institute, SP102, pages 14-24, 1987. 
Appendix

Experimental Data 
Table 11 Corrosion rate of steel in concrete blocks immersed in 1.7 and $3 \%$ sodium chloride solutions

\begin{tabular}{|c|c|c|c|c|}
\hline \multicolumn{5}{|c|}{ Concrete blocks immersed in $1.7 \%$ sodium chloride solution } \\
\hline & \multirow{2}{*}{ Specimen } & \multicolumn{3}{|c|}{ Duration in days } \\
\hline & & 32 & 72 & 132 \\
\hline \multirow{6}{*}{$\begin{array}{l}\text { Polarization } \\
\text { Resistance in } \\
\text { Ohms }\end{array}$} & 1 & 0.000124 & 0.0003 & 0.0005 \\
\hline & 2 & 0.000090 & 0.0003 & 0.0005 \\
\hline & 3 & 0.000110 & 0.0003 & 0.0004 \\
\hline & 4 & 0.000116 & 0.0004 & 0.0007 \\
\hline & 5 & 0.000149 & 0.0008 & 0.0012 \\
\hline & 6 & 0.000158 & 0.0006 & 0.0008 \\
\hline \multirow{6}{*}{$\begin{array}{l}\text { Corrosion Rate } \\
\text { in } \mathrm{mA} / \mathrm{m}^{2}\end{array}$} & 1 & 0.6232 & 1.5091 & 2.5156 \\
\hline & 2 & 0.4532 & 1.5091 & 2.5156 \\
\hline & 3 & 0.5533 & 1.5091 & 2.0118 \\
\hline & 4 & 0.5834 & 2.0118 & 3.5209 \\
\hline & 5 & 0.7492 & 4.0237 & 6.0366 \\
\hline & 6 & 0.7944 & 3.0183 & 4.0237 \\
\hline \multirow{6}{*}{$\begin{array}{l}\text { Corrosion Rate } \\
\text { in MPY }\end{array}$} & 1 & 0.0285 & 0.0689 & 0.1148 \\
\hline & 2 & 0.0207 & 0.0689 & 0.1148 \\
\hline & 3 & 0.0253 & 0.0689 & 0.0919 \\
\hline & 4 & 0.0266 & 0.0919 & 0.1608 \\
\hline & 5 & 0.0342 & 0.1837 & 0.2756 \\
\hline & 6 & 0.0363 & 0.1378 & 0.1837 \\
\hline \multirow{2}{*}{$\begin{array}{l}\text { Average } \\
\text { Corrosion Rate } \\
\text { in } \mathrm{mA} / \mathrm{m}^{2}\end{array}$} & HC steel & 0.5432 & 1.5091 & 2.3477 \\
\hline & CV steel & 0.709 & 3.0179 & 4.5271 \\
\hline
\end{tabular}




\begin{tabular}{|c|c|c|c|c|}
\hline \multicolumn{5}{|c|}{ Concrete blocks immersed in $3 \%$ sodium chloride solution } \\
\hline & \multirow{2}{*}{ Specimen } & \multicolumn{3}{|c|}{ Duration in days } \\
\hline & & 32 & 72 & 132 \\
\hline \multirow{6}{*}{$\begin{array}{l}\text { Polarization } \\
\text { Resistance in } \\
\text { Ohms }\end{array}$} & 7 & 0.0003 & 0.0004 & 0.0005 \\
\hline & 8 & 0.0004 & 0.0005 & 0.0006 \\
\hline & 9 & 0.0004 & 0.0005 & 0.0006 \\
\hline & 10 & 0.0007 & 0.0010 & 0.0011 \\
\hline & 11 & 0.0010 & 0.0013 & 0.0015 \\
\hline & 12 & 0.0006 & 0.0011 & 0.0011 \\
\hline \multirow{6}{*}{$\begin{array}{l}\text { Corrosion Rate } \\
\text { in } \mathrm{mA} / \mathrm{m}^{2}\end{array}$} & 7 & 1.5091 & 2.0118 & 2.5156 \\
\hline & 8 & 2.0118 & 2.5156 & 3.0182 \\
\hline & 9 & 2.0118 & 2.5156 & 3.0182 \\
\hline & 10 & 3.5209 & 5.0301 & 5.5328 \\
\hline & 11 & 5.0301 & 6.5393 & 7.5457 \\
\hline & 12 & 3.0182 & 5.5328 & 5.5328 \\
\hline \multirow{6}{*}{$\begin{array}{l}\text { Corrosion Rate } \\
\text { in MPY }\end{array}$} & 7 & 0.0689 & 0.0919 & 0.1148 \\
\hline & 8 & 0.0919 & 0.1148 & 0.1378 \\
\hline & 9 & 0.0919 & 0.1148 & 0.1378 \\
\hline & 10 & 0.1608 & 0.2297 & 0.2527 \\
\hline & 11 & 0.2297 & 0.2986 & 0.3445 \\
\hline & 12 & 0.1378 & 0.2527 & 0.2527 \\
\hline \multirow{2}{*}{$\begin{array}{l}\text { Average } \\
\text { Corrosion Rate } \\
\text { in } \mathrm{mA} / \mathrm{m}^{2}\end{array}$} & HC steel & 1.8439 & 2.3477 & 2.8504 \\
\hline & CV steel & 3.8568 & 5.7008 & 6.2045 \\
\hline
\end{tabular}


Table 12 Percent weight loss of $\mathrm{HC}$ and CV steel rebars in different sodium chloride concentrations

\begin{tabular}{|c|c|c|c|c|}
\hline \multirow{2}{*}{$\begin{array}{l}\text { Sodium } \\
\text { chloride } \\
\text { concentration }\end{array}$} & \multirow{2}{*}{ Specimen } & \multicolumn{3}{|c|}{ Percent weight loss during the time periods in days } \\
\hline & & 16 & 23 & 30 \\
\hline \multirow{6}{*}{$0.1 \%$} & $\mathrm{a}$ & 0.0282 (14 days) & 0.0569 & \\
\hline & $\mathrm{b}$ & 0.0266 & 0.0787 & \\
\hline & $\mathrm{c}$ & 0.0691 & 0.1240 & \\
\hline & $\mathrm{d}$ & 0.6753 & 1.0218 & \\
\hline & $\mathrm{e}$ & 0.8098 & 1.2204 & \\
\hline & $\mathrm{f}$ & 0.7949 & 1.1267 & \\
\hline \multirow{6}{*}{$0.5 \%$} & $\mathrm{~g}$ & 0.2043 & 0.3525 & \\
\hline & $\mathrm{h}$ & 0.1770 & 0.3094 & \\
\hline & $\mathrm{i}$ & 0.1745 & 0.3028 & \\
\hline & $\mathrm{j}$ & 0.6476 & 1.1524 & \\
\hline & $\mathrm{k}$ & 0.7506 & 1.1472 & \\
\hline & 1 & 0.7059 & 1.1756 & \\
\hline \multirow{6}{*}{$1.7 \%$} & $\mathrm{~m}$ & 0.2402 & 0.3537 & 0.4307 \\
\hline & $\mathrm{n}$ & 0.2800 & 0.3922 & 0.4919 \\
\hline & o & 0.2309 & 0.3453 & 0.4261 \\
\hline & $\mathrm{p}$ & 0.9174 & 1.3159 & 1.7030 \\
\hline & $\mathrm{q}$ & 0.9360 & 1.2125 & 1.5781 \\
\hline & $\mathrm{r}$ & 0.8633 & 1.2739 & 1.6597 \\
\hline \multirow{6}{*}{$3 \%$} & $\mathrm{~S}$ & 0.4002 & 0.6027 & 0.7912 \\
\hline & $\mathrm{t}$ & 0.3723 & 0.5122 & 0.6027 \\
\hline & $\mathrm{u}$ & 0.4761 & 0.7198 & 0.9174 \\
\hline & $\mathrm{v}$ & 0.8699 & 1.2050 & 1.4944 \\
\hline & $\mathrm{w}$ & 0.8283 & 1.1591 & 1.4708 \\
\hline & $\mathrm{x}$ & 0.8931 & 1.1900 & 1.6774 \\
\hline
\end{tabular}

